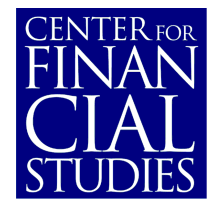

No. $2003 / 19$

Regulation and Competition in German Banking: An Assessment

Karl-Hermann Fischer*, Christian Pfeil

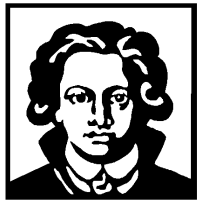


CFS Working Paper No. 2003/19

\title{
Regulation and Competition in German Banking: An Assessment
}

\author{
Karl-Hermann Fischer* Christian Pfeil
}

June 2003

\begin{abstract}
:
In Germany a public discussion on the "power of banks" has been going on for decades now with the term "power" having at least two meanings. On the one hand, it denotes the power of banks to control public corporations through direct shareholdings or the exercise of proxy votes - this is the power of banks in corporate control. On the other hand, the market power derived from imperfect competition in markets for financial services is implied, which banks exercise vis-à-vis their loan and deposit customers. In the past, bank regulation has often been blamed for undermining competition and the functioning of market forces in the financial industry for the sake of soundness and the stability of financial services firms. This chapter tries to shed some light on the historical development and current state of bank regulation in Germany. In so doing, it tries to embed the analysis of bank regulation in a more general industrial organization framework. For every regulated industry, competition and regulation are deeply interrelated as most regulatory institutions, even if they do not explicitly address the competitiveness of the market, affect either market structure or conduct. This paper aims to uncover some of the specific relationships between monetary policy, government intervention and bank regulation on the one hand and bank market structure and economic performance on the other. We hope thereby to be able to point the way to several areas for fruitful research in the future. While our focus is on Germany, some of the questions that we raise and some of our insights might also be applicable to banking systems elsewhere.
\end{abstract}

Keywords: German Banking, Market Structure, Regulation JEL Classification: G28, G21, L11, L51

\footnotetext{
*corresponding author: Department of Finance, JW Goethe University, Mertonstraße 17-21, 60054- Frankfurt am Main, Germany, Email: kafische@wiwi.uni-frankfurt.de

The authors would like to thank Martin Hellwig (the referee) for very helpful comments and suggestions. We further would like to thank Horst Bertram, Hannah S. Hempell and Reinhard H. Schmidt for valuable comments. The provision of data from Deutsche Bundesbank, Verband der Vereine Creditreform e.V. and Worldbank is gratefully acknowledged. All errors and inaccuracies remain - of course - our own responsibility. Forthcoming in: The German Financial System by Jan P. Krahnen and Reinhard H. Schmidt, Oxford University Press.
} 
1. German banking - stability and market power

\subsection{Introduction}

According to a widely held view, German banking in the past has been stable but not very competitive. ${ }^{1}$ Although there have been difficulties with single banking institutions Bankhaus Herstadt and Schröder, Münchmeyer \& Hengst are well-known examples - no widespread systemic crisis has occurred for decades. It is only very recently that word of a "banking crisis" has spread over Germany, a phenomenon which we will be discussing in more detail below. ${ }^{2}$ Between the end of World War II and early 2002, however, the banking industry seemed to operate smoothly. Many observers believe that the second characteristic, i.e. the lack of competitive pressure in Germany's financial system, was nothing less than the flip side of this medal. Bank regulation in Germany - so the argument goes - had achieved its stability goal mainly by restricting competition in the financial services sector and by sheltering Germany's universal banks from competition with foreign banks and non-bank suppliers of financial services. Furthermore, regulators and politicians were believed to have fostered cartelization of the industry and to have favored national champions. Like in other European countries, regulatory capture seemed to be a widespread phenomenon in the past.

In Germany a public discussion on the "power of banks" has been going on for decades now with the term "power" having at least two meanings. On the one hand, it denotes the power of banks to control public corporations through direct shareholdings or the exercise of proxy votes - this is the power of banks in corporate control. On the other hand, the market power derived from imperfect competition in markets for financial services is implied, which banks exercise vis-à-vis their loan and deposit customers. ${ }^{3}$

Given such a strong public perception inside and outside Germany, it is not surprising that the regulatory regime in Germany is most often interpreted as an attempt to trade off the stabilizing effects of bank market power against the efficiency benefits of more intense

\footnotetext{
${ }^{1}$ See Saunders/Walter (1994), Allen/Gale (2000), Rajan (1996), Gual/Neven (1993), or Beck (2000) for such evaluations!

${ }^{2}$ We will refer to this point in section 3. below. At the time of writing in spring 2003, the "German banking crisis" still remains in a somewhat unresolved state. While no serious banking failures have occurred to date, accelerating default rates among non-bank enterprises and a weak outlook for the German economy still raise fears that the danger of a systemic disruption of the banking system is not yet fully averted.

${ }^{3}$ Interestingly, in the political arena, most attempts to restrict bank powers in Germany in the past were aimed at restricting their dominance in corporate control.
} 
competition in financial services. ${ }^{4}$ According to this view, bank regulators have used means of anti-competitive regulation to make banking a "safe haven" i.e. not vulnerable to excessive risk taking. More recently however, important measures towards deregulation of the banking industry were taken at the European level. Anti-competition regulations have been abolished and the remaining regulatory structure does more to directly address the primary goal of bank regulation, that is a reduction of risk of bank failures. As a consequence of deregulation, there is little doubt among industry observers that banking all over Europe, and in Germany as well, has become significantly more competitive. ${ }^{5}$

Although we find this overall assessment of the past and present of bank regulation in Germany convincing, we believe that there is more to the story. While deregulation in financial services has been greatly applauded by many economists and the public since its beginning in the mid-1980s, for some skeptics the joint occurrence of unfettered competition in banking on the one hand and crisis-type phenomena observed around the world on the other, is more than just a coincidence. Furthermore, from our perspective, several of the more important questions have remained largely unanswered. Why have regulators' attitudes towards competition in financial services changed so dramatically? Will deregulation keep its promises? What will the long-term competitive effects of internationally harmonized prudential regulations (capital requirements, market discipline, supervision) be in national markets that have taken such different roads in the past? While cross-country empirical work has made significant contributions to recent research in this area, we believe that evaluations of the historical performance of single country banking systems are at least as important.

This chapter therefore tries to shed some light on the development and current state of bank regulation in Germany. ${ }^{6}$ In so doing, it tries to embed the analysis of bank regulation in a more general industrial organization framework. For every regulated industry, competition and regulation are deeply interrelated since most regulatory institutions, even if they do not explicitly address the competitiveness of the market, either affect market structure or conduct. ${ }^{7}$ Moreover, discussions on bank regulation, instead of referring to single regulatory institutions, might more usefully be directed towards what has recently been termed the

\footnotetext{
${ }^{4}$ As an example see Franke's (2000) assessment.

${ }^{5}$ In addition, advances in information technology and applied finance have had a strong impact on competitive conduct in financial services.

${ }^{6}$ Our focus, however, is on regulations pertaining to commercial banking activities and as such only provides a discussion on selected aspects of the regulation of universal banks.

7 See Vives (1991) or Cerasi et al. (1998).
} 
regulatory regime. In addition to analyzing the traditional instruments of bank regulation (capital requirements or deposit insurance), according to Llewellyn (2001) a regulatory regime perspective also takes the role of market discipline and banks' internal corporate governance arrangements into account. Therefore, throughout this chapter, a recurring theme will be specific types of governance structures that dominate in German banks and the role of the public banking sector in Germany in particular. We believe that the importance of these structural features of the banking system can hardly be overestimated. For instance, we will argue that "government ownership of banks" might mean different things in different countries and we will point to several peculiarities of the German case. ${ }^{8}$ While our approach is mainly descriptive we also try to uncover some of the specific relationships between monetary policy, government interference and bank regulation on the one hand and bank market structure and economic performance on the other. We hope thereby to be able to point to several areas for fruitful research in the future. While our focus is on Germany, some of the questions that we raise and some of our answers might also be applicable to banking systems elsewhere.

To emphasize the relevance of our perspective, in section 1.2 we first briefly review different approaches to interpreting anti-competitive regulation in financial markets. Whether standard theory provides useful guidelines for explaining the causes and consequences of bank regulation in Germany, will then be discussed. In order to allow a first assessment, in section 1.3 we take a birds' eye's view of the history of bank regulation in Germany,outlining how it has evolved since its beginnings in the 1930s. This discussion of the sequence of regulatory activities allows us to identify both the fundamental structure of the regulatory regime, and the driving forces behind its adjustment over time. Section 1.4 reviews empirical evidence on market structure and market power in German banking. We then turn to a more detailed evaluation of the interrelationship between regulation on the one hand and competitiveness and bank market power on the other. In section 2 our discussion thus focuses on selected aspects of bank regulation and bank market structure in Germany and tries to provide data and empirical evidence whenever available. Based on our results, section 3 concludes and discusses what might be expected for the future.

1.2 Public interventions in financial services - the public and the private interest

\footnotetext{
${ }^{8}$ Given the importance of government ownership of banks around the world, every discussion about public regulation of banking should take public banking into account as well. See La Porta et al. (2002) for empirical evidence on the pervasiveness of government ownership of banks.
} 
It is now well recognized that the regulation of banks has important implications for the shape and functioning of a financial system and the economy as a whole. While this claim seems to be widely accepted among economists, politicians and bank regulators and supervisors, international differences in bank regulation indicate that there is much less consensus on how it best serves its goals and probably even what these goals are. Yet, what most discussions on bank regulation - academic or more policy oriented - have in common, is that they look at bank regulation from a "public interest" perspective. Government intervention serves to cure market failures that would otherwise threaten the functioning of the financial system. The historical experience with banking crises in many countries strongly underlines the need to impose limitations on the discretion of bank owners and managers. Theoretical work has pointed to inherent instabilities of the banking business and highlighted the potential for severe problems based on asymmetries of information and asset substitution type riskshifting. ${ }^{9}$ Banks throughout the world are highly leveraged and normally the base of investors in their debt instruments, i.e. bank deposits, is widely dispersed. The large share of debt in banks' capital structures increases the risk of default and as a consequence might trigger excessive risk taking in certain economic environments. The wide dispersion of relatively small depositors limits the willingness of these debt-holders to act as an effective monitor. Furthermore, the social cost of the failure of banking institutions is perceived to be high. ${ }^{10}$ All these fundamental reasons for regulating banks are well-known and we need not reiterate them here in any more detail. ${ }^{11}$ Historically, the rationale for bank regulation in Germany is also in keeping with these arguments and is primarily aimed at protecting depositors as well as safeguarding the viability of banks and the functioning of the financial sector as a whole. ${ }^{12}$ However, from this prudential perspective, it is not immediately clear where a trade-off between competition and stability could arise. Why should bank regulators, pursuing the public interest (stability of the financial system and protection of depositors), choose to restrict competition in banking, thereby laying a well-known burden on society as a whole? One explanation that has gained prominence recently may be summarized as follows: bank

\footnotetext{
${ }^{9}$ See Bhattacharya/Boot/Thakor (1998) for an overview.

${ }^{10}$ The "shock waves" generated by banking crises often affect the whole economy. See Stiglitz (2001) for a discussion..

${ }^{11}$ See Bhattacharya/Boot/Thakor (1998), Dewatripont/Tirole (1994) or Freixas/Rochet (1997) for in-depth discussions.

${ }^{12}$ It is assumed that the banking business is especially sensitive to depositor confidence. Moreover, bank regulation has a strong social impetus as the small depositor is seen as being in need of protection against losses caused by bank failures.
} 
regulation is best described as taking place in an environment of asymmetric information between depositors and banks and is therefore characterized by moral hazard and assetsubstitution type risk-shifting incentives on the part of banks. There is, of course, a long history of widespread banking crisis, sustained periods of lack of depositor confidence and many examples of outright fraud. One possible and forceful regulatory remedy to these problems is to restrict competition in financial services and to create positive bank charter values. A franchise value of banks, caused by imperfect competition in banking markets, gives bankers something to lose in case of default. ${ }^{13}$ The threat of losing a valuable charter whenever a bank is closed by regulators makes bankers more conservative and deters excessive risk taking. Recent regulatory reforms, by putting more emphasis on safety and soundness of banks and abolishing anti-competition regulations, might therefore be based on the implicit assumption that the informational gap between financial markets, bank depositors and bank regulators on the one hand and bank managers and owners on the other has become narrower over the last two decades.

A less naive alternative to the public interest view is the capture theory or "private interest view" that interprets regulation as the attempt by a well-organized regulated industry to use the sovereign power of the state to capture rents at the expense of customers and society as a whole. ${ }^{14}$ This perspective seemed to have played an important role among industry observers and academics in explaining the perceived low degree of competitiveness in European banking in the past. In 1991 Xavier Vives predicted "[...] the main effect of integration will be to change the focal point of the strategies of banks from collusion and regulatory capture to competition" 15 . Given that the banking industry seems to have well-organized lobbying instruments at its disposal, to what extent was regulation in the past triggered by the industry's desire to deter competition in financial services?

There might also be a different type of regulatory capture in banking, combining two of the aspects of public and private interest mentioned above. In the UK, for instance, the Cruickshank report suspected that there has been "an informal contract between successive governments and banks, designed to deliver public confidence in the banking system. In

\footnotetext{
${ }^{13}$ See the paper by Demsetz et al. (1996) for instance.

${ }^{14}$ See Stigler (1971) and for a brief sketch Kroszner/Strahan (1999).

${ }^{15}$ See Vives (1991), p. 17.
} 
return for cooperating in the delivery of Government objectives, the banking industry escaped the rigors of effective competition." 16

Finally, a closely related view on regulation might be termed the "grabbing hands view". ${ }^{17}$ From this perspective neither the public interest nor the regulated industry, but rather politicians and state officials drive regulatory actions and interfere with the regulated industry in order to extract benefits and pursue their own interests. As Hellwig (2001) points out, the banking industry is especially vulnerable to encouraging greediness on the part of politicians. Politicians like to exercise control over banks because the banking business provides a unique and most direct opportunity to spend money and fund projects that serve the politicians' own purposes. It is worth noting here and for the remainder of this chapter that while we primarily address bank regulation our regulatory regime perspective necessarily leads us to consider government ownership of banks as well. The interrelationships between regulation and government ownership of banks is at least threefold. Firstly, governance and incentive structures in government-owned banks are likely to be different from those in privately owned, value-maximizing banks that have traditionally been the focal point of almost all discussions on bank regulation. Secondly, in a country where a large share of bank assets is already under the control of the state, politicians' attitudes towards regulating banks might be different by comparison to a private banking system. For instance, the nationalization of single banks or the banking system as a whole has historically been one forceful governmental remedy for banking crises and can thus be interpreted as a means of bank regulation itself. Thirdly, one has to ask how competition in financial services is affected when some banks are state-owned while others are not.

Recent cross-country empirical work by La Porta et al. (2002) analyzes the consequences of government ownership of banks and indicates that a higher share of bank assets controlled by government negatively correlates with subsequent financial development and subsequent rates of growth in GDP. These findings can be interpreted as evidence supporting the capture theory of regulation or the "grabbing-hands view" of government intervention in financial markets and thus reinforce a commonly held notion: Government involvement in the capital allocation process yields inefficient outcomes because it distorts the price system, favors corruption and undermines the functioning of the market.

\footnotetext{
${ }^{16}$ Cruickshank (2000), p. vii (Executive Summary)

${ }^{17}$ This term is adopted from Shleifer/Vishny (1999).
} 
At first glance, the structure of the German banking system seems to be especially exposed to inefficiencies arising from regulatory capture and politicians' grabbing hands. A significant share of bank assets in Germany is under the control of the state. La Porta et al. (2002) measure the share of government ownership in Germany as 51,90\% in 1970 and 36,36\% in 1995. Although only based on observing the ten largest banks in the country, these figures capture the overall share of public ownership fairly well. At the end of 2001 the share of Landesbanks (central giro institutions of the Federal States) in total bank assets in Germany was $19,9 \%$ and that of municipal savings banks was $15,4 \%$. Adding public mortgage banks, public building societies and public special purpose banks, the share of public banks in total banking assets is estimated to be somewhat above $40 \% .{ }^{18}$ While La Porta et al. (2002) use the term "government ownership", we will refer to these institutions as "public banks" in the remainder of this chapter. ${ }^{19}$ From our perspective, this is more than just a terminological note because in Germany all levels of regional authorities own and control banks. While municipalities own more than 500 savings banks, almost all German states ${ }^{20}$ hold ownership stakes in one of the 12 Landesbanks and besides often own state-level development banks. In addition, the Federal Government owns Kreditanstalt für Wiederaufbau (KfW) and Deutsche Ausgleichsbank (DtA), two large development banks.

Politicians, especially at the municipal and state level thus often seemed in the past to exert direct control over bank assets because states and municipalities acted as a guarantors for the liabilities of the savings banks and Landesbanks (guarantee obligation or Gewährträgerhaftung) and by law were required to ensure the viability of these public enterprises (maintenance obligation or Anstaltslast). For example, they had to provide capital in the event of a reorganization. ${ }^{21}$ State governments use the Landesbanks as their own development banks and directly pursue what is officially stated to be the interest of the state in terms of regional economic development. The same can be said about public savings banks and the influence exerted by politicians at the municipal level. As is well known, in 2002 an agreement was reached between the European Commission, the German authorities and the

\footnotetext{
${ }^{18}$ As of year end 2000, five of the ten largest banks and nine out of the fifteen largest banks belong to the public sector. In terms of total assets and measured for the ten largest banks the figure comparable to La Porta et al. (2002) for 2000 is $33 \%$.

${ }^{19}$ Obviously, with "public banks" we are not referring to banks who have issued shares of common stock and whose shares are traded on exchanges.

${ }^{20}$ Only the state of Rhineland-Palantine does not hold ownership stakes in a Landbank.

${ }^{21}$ This is often termed „maintenance obligation“. As public sector banks in trouble are always rescued because of the maintenance obligation, the guarantor obligation has never been called for. For further discussion see Hackethal (2003).
} 
public banking sector to abolish state and municipal guarantees and significantly modify obligations to ensure the banking institution's viability. We will address these more recent developments and their likely consequences in section 3 below.

It is important to note, however, that ownership in most public banks is far from monolithic. While municipal savings banks are usually owned by groups of municipalities, Landesbanks in aggregate are owned by states and the regional associations of municipal savings banks. Furthermore, cross-ownership is important among Landesbanks. The process of decisionmaking within Landesbanks might as a consequence be characterized by conflicts of interest. It is therefore not immediately clear how different interest groups - politicians, public banks' managers, as well as the public banks' associations at the state or federal level - contribute to what could be termed the corporate governance of German public banks. Also, in addition to the "grabbing hands" hypothesis on public interference in banking, there is a competing view, termed the "development view" by La Porta et al. (2002). Based on the notion that financial markets are characterized by important market imperfections and given that financial development is beneficial in that it fosters economic growth, governments might also have a positive role to play. From a theoretical point of view, it cannot be entirely ruled out that public banks would be better able to provide financial services to certain groups of customers when market imperfections are significant. Moreover, private shareholder value-maximizing banks in such a market environment might be forced to focus their supply of financial services on the least risky and most profitable customers, leaving others "unbanked". Thus it is the case thatsavings banks and state owned Landesbanks have a disproportionately larger market share in financing small, young and risky corporate customers. ${ }^{22}$

Whether the "grabbing hands" view or the "development view" does a better job in explaining the history of public banks in Germany and whether the results of La Porta et al. (2002) also apply in the German case remains an open question and more research is definitely required. Did the existence of such a large public banking sector cause capital to be allocated inefficiently and as a consequence lead to lower economic growth? ${ }^{23}$ As we are primarily interested in regulation we also have to ask whether inefficient public banks lead regulators

\footnotetext{
${ }^{22}$ Municipal savings banks for instance do grant $64 \%$ of all loans to small craftsmen and provide around $50 \%$ of financing to newly created enterprises.

${ }^{23}$ Two questions are of importance here. (1) Does corporate control exercised by politicians lead to the inefficient allocation of capital? And more fundamentally, (2) does the governance structure of public banking institutions by its very nature lead to inefficient outcomes?
} 
and policymakers to restrict competitive pressure in order to allow these institutions a "quiet life".

Answers to all the questions raised in this section are far from being straightforward, but we will try to discuss them in more detail in section 2 when we assess single regulatory instruments. It is important to note, however, that from the researcher's perspective it is inherently difficult to analyze how a given regulation affects industry profits ${ }^{24}$ and even more so, to find out how different interest groups contribute to the regulatory process.

Unfortunately once again, empirical work on this issue is virtually non-existent in Germany. ${ }^{25}$ In what follows, we therefore first briefly review the history of bank regulation in Germany. Our aim is to sketch the fundamental structure of the regulatory regime as well as the driving forces behind its adjustment over time.

\subsection{Regulation in German banking - a short historical overview}

The beginning of banking regulation in Germany dates back to 1931, when licensing requirements and bank supervision were first introduced on a general scale and a supervisory authority was set up. Before that, only public sector savings banks and mortgage banks had been subject to regulation and supervision. Like in many other countries, bank regulation in Germany can be interpreted primarily as a response to banking crises. The 1931 initiatives, for example, followed the general banking crisis culminating in the default of the Danatbank. As a further response and in an attempt to consolidate the provisions passed so far, the first German banking law was enacted in 1934.

It is important to note that when bank regulation began in the 1930s the fundamental structure of the German banking system, a mix of private, public and co-operative institutions, was already in place. Moreover, all three groups of banks had already established banking associations at the national as well as the regional level.

\footnotetext{
${ }^{24}$ This task is further complicated by the possibility that certain stakeholders might extract part of these rents.

${ }^{25}$ Analyses of the effect of regulation on industry profits often use the event study method, measuring the stock price reaction of regulated firms to regulatory announcements. One such study conducted by one of the authors will be presented further below in section 2.2. Further, in the US several studies analyse congressional voting behavior to indirectly infer interest group influence. See Kroszner/Strahan (1998) as an example for the latter group of studies. Unfortunately there is no comparable empirical work for Germany.
} 
While in the US or UK, mandatory capital requirements were first implemented in the 1980s, regulation of bank capital has a long tradition in Germany $\cdot{ }^{26}$ For example, mortgage banks were subject to structural norms tied to an institution's equity capital as early as 1899 . The German Banking Act of 1934 defined a credit institution's capital, termed "liable capital", by enumerating respective balance sheet items. Further it made "liable capital" a point of reference for specific horizontal as well as vertical structural balance sheet rules.

Interestingly, the early capital requirements primarily served the purpose of limiting maturity mismatch between banks ' assets and liabilities by requiring banks to hold capital in relation to the difference between customer liabilities and liquid assets. Regulators as well as academics at that time were well aware of the potential losses that banks could suffer whenever they were forced to sell off their illiquid loans. Therefore, instead of requiring banks to hold capital in relation to an overall measure of asset risk, two further structural norms of the 1934 Banking Act limited the amount of lending to single borrowers and an institution's investment in real estate and long-term participating interest to a certain proportion of capital.

Supported by the Nazi government, in 1937 German banks entered into a cartel-like agreement on interest rates, fees and advertising. The Central Credit Committee (Zentraler Kreditausschuss) was established as a platform for private, co-operative and public banks in 1936 in order to co-ordinate banks' business decisions and ceilings on loan and deposit interest rates. Although no such cartels have remained in place, today the Central Credit Committee still exists and serves as an integrated lobbying platform for all German banking associations - co-operative, public and private - as well as a contact to the banking industry for regulators and administrative institutions.

After World War II the 1934 Banking Act also formed the basis for bank regulation, which was first exercised by the western allies" military administration and then passed over to the states and their authorities. In a remarkable step in 1958 branching restrictions were abolished and banking institutions were free to open branches everywhere in the country without passing a public needs test. However because public savings banks are closely tied to their municipalities' market areas and in general do not invade each others' local markets, the economic effect of this deregulation might not have been as significant as comparable measures taken by US states during the 1978 to 1992 period. $^{27}$

\footnotetext{
${ }^{26}$ See Krümmel (1983) for a short survey of the history of capital regulation.

${ }^{27}$ See Berger et al. (1995) and Jayaratne/Strahan (1996) for an evaluation of branching deregulation in the US. We will highlight the role and structure of the bank branching network in Germany further below.
} 
With the passage of the new German Banking Act (Kreditwesengesetz) in 1961 bank supervisory activities were centralized at the federal level and passed over to the newly established Federal Banking Supervisory Office (Bundesaufsichtsamt für das Kreditwesen or FBSO in what follows). From its beginning the law required the Bundesbank to be involved in the supervisory process. ${ }^{28}$ In addition, in every single state there has to be a supervisory authority for public savings banks. The FBSO is responsible for supervising banks; it grants and revokes banking licenses and supervises the ongoing business activities of banks. The FBSO has far reaching rights to obtain information, intervene into management decisions, recall bank managers, impose moratoria and close a bank. It is worth emphasizing that in Germany there is a supervisory agency which is separate from the central bank but the Bundesbank is actively involved in banking supervision and significantly supports the FBSO $^{29}$. The Bundesbank plays an important role in virtually all areas of banking supervision with a special emphasis on activities related to collecting and processing relevant information. In particular, it is involved in "the issuing of general rules (such as principles and regulations), the process of ongoing supervision, with the exception of (sovereign) individual regulatory measures vis-à-vis institutions, prudential audits and, international cooperation/coordination in the prudential field". ${ }^{30}$ The Bundesbank also plays an important role in crisis management. ${ }^{31}$

One of the main arguments in favor of involving the Bundesbank in the supervisory process lies in the informational economies of scope between monetary policy, bank supervision and crisis management in particular ${ }^{32}$. While the allocation of supervisory duties is relatively clear, the question of who actually "makes regulation" in Germany is much harder to answer, with the German Parliament, the Ministry of Finance and the supervisory authorities (FBSO and the Bundesbank) all being involved. Furthermore and as already mentioned above, the role played by the banking industry itself should be critically assessed.

\footnotetext{
${ }^{28}$ An interesting remark concerns the fact that the law was enacted against the will of the states, who instituted proceedings against it at the Federal Constitutional Court (Bundesverfassungsgericht). In its opinion the Court emphasized that bank supervision is an integral part of a central bank's area of responsibilities.

${ }^{29}$ In several European countries - for instance in Greece, Ireland, Italy, the Netherlands, Portugal or Spain - the central bank is the only supervisory agency.

${ }^{30}$ See Bundesbank (2000) and the Bundesbank's (www.bundesbank.de) website for further details.

${ }^{31}$ For readers interested in the subject, we have listed several websites on German banking in the Appendix. The Bundesbank's website address is also listed there.

${ }^{32}$ See also Vives (2000).
} 
According to the Banking Act, the FBSO is required to draw up principles allowing it to assess whether a bank's liquidity and capital is adequate. From 1961 onwards, therefore, German credit institutions were subject to the so-called Principle I that limited a bank's credit risk by requiring them to hold an appropriate amount of capital relative to the sum of riskweighted assets. Principles II and III, like their predecessors in the Banking Act of 1934, were primarily concerned with maturity mismatch and required assets of certain maturity to be related to liabilities of similar maturity. With respect to interest rates, cartel-like agreements among banks remained in place until 1965. Although the 1961 Banking Act already formed the legal basis for federal interest rate regulations, the FBSO only made use of it during the 1965 to 1967 period. In 1967 all regulations on interest rates were abolished and since then loan and deposit rates have been free to adjust to market conditions. ${ }^{33}$ In addition to its involvement in the supervisory process, the Bundesbank has always been an important player in every decision on financial market regulation and in some instances has protected German banks from foreign or non-bank competition. For example, at the end of the 1960s the increased desire of foreign entities to issue bonds denominated in DM posed a threat to the Bundesbank's strategy to prevent the DM from becoming an international reserve currency. In 1968, therefore, the Bundesbank settled an agreement with the German banks - the so called "Gentlemen's Agreement" - that only a German bank could act as lead underwriter of DMdenominated issues of foreign entities. This effectively restricted competition from foreign banks. ${ }^{34}$ The scope of the "Gentlemen's Agreement" was expanded further in 1980 before it was abolished in 1985.

The 1961 Banking Act remained largely unchanged until the next significant crisis occurred in 1974, when Bankhaus Herstatt collapsed as a consequence of large speculative positions in foreign exchange. The Herstatt crisis, which according to Herring/Litan (1995) had a significant effect, despite the small size of the bank, on banks world wide, led to several new regulatory initiatives: Firstly, a system of group-specific deposit insurance schemes was established. It replaced the rudimentary systems that had existed since 1969. The newly created system of deposit insurance schemes was unique in that deposit insurance was and still is entirely in the hands of the banking groups (co-operatives, public and private banks)

\footnotetext{
${ }^{33}$ Reserve requirements on bank deposits, however, still drive a wedge between money market rates and bank deposit rates.

${ }^{34}$ Proceeds from the issues were immediately converted into the issuer's home currency and transferred to him. Bilateral agreements with other central banks further ensured that no DM-bonds were issued outside Germany. See Franke (2000) for further details.
} 
themselves. We will provide a more detailed analysis of deposit insurance in Germany further below. As a further response to the Herstatt crisis, the so called Liquiditätskonsortialbank (liquidity bank)was founded in order to assist solvent but illiquid private banks. New structural norms, termed Principle Ia, were introduced by the FBSO to tie open positions in foreign exchange and precious metals to a bank's capital. The 1976 amendment to the Banking Act further authorized the FBSO to audit single institutions without special reason and defined limits on losses experienced by credit institutions that lead to mandatory closure by the FBSO. Finally, in 1974 an expert group was implemented to consult the government with respect to fundamental questions of the banking industry. ${ }^{35}$

It may, however, be seriously doubted whether any of these reforms directly addressed the weaknesses in the supervisory system that the Herstatt crisis had uncovered, namely that of timely and accurate information in the hands of the supervisors. This information necessarily forms the basis of a functioning early warning system. Whether the supervisory agency's ability to detect problems in single banks has since improved, remains somewhat unclear. According to Beck (2001), when Bankhaus Schröder, Münchmeyer \& Hengst nearly failed in 1983 due to large loan losses, these problems were first discovered by the Association of Private Banks (Bundesverband deutscher Banken), not by the FBSO! ${ }^{36}$

The third amendment to the Banking Act came into force in 1985 and required capital adequacy regulations to be met both by individual institutions as well as on a consolidated basis. Prior to 1985 banks were permitted to build up credit pyramids through their subsidiaries without adequately adjusting the parent bank's capital base. Furthermore and as a direct response to the Schröder, Münchmeyer \& Hengst case, the limit for lending to a single borrowing entity was reduced from $75 \%$ to $50 \%$ of capital. Principle Ia that tied a bank's exposure in foreign currencies and precious metals to its capital was revised in 1990 to also cover price risk from derivatives and interest rate exposures.

Further amendments to the Banking Act primarily served to transpose European Directives into German law. The fourth amendment in 1993 implemented the Solvency Ratio and first Capital Adequacy Directive and raised the threshold of the reporting requirement for large loans from around $€ 500,000$ to $€ 1,500,000$. Since the mid 1930s German banks have been

\footnotetext{
${ }^{35}$ See Krümmel (1980) for a report.

${ }^{36}$ Schröder, Münchmeyer \& Hengst had lend heavily to building machinery group IBH. See Goodhart/Schoenmaker (1993) for a short description.
} 
required to report all large loans to a central credit register maintained by the central bank. After consolidating these reports, the Bundesbank notifies the lending banks of the overall indebtedness of their borrowers. It is interesting to note that the first Basle Accord, underlying the Capital Adequacy Directive, was accompanied by heavy discussions with respect to its effect on the international competitiveness of German banks. ${ }^{37}$ While the competitiveness of domestic banks in the international marketplace was still an issue when the so called Basle II program was made public in 1999, in Germany discussions on Basle II now focus much more attention on questions related to capital requirements, internal rating systems and bank loan supply to SMEs.

In 1994 and after six years of intense debate, money market mutual funds were allowed to operate in Germany posing a serious competitive threat to German banks' deposit business. In the preceding years the Bundesbank especially had strongly opposed the necessary changes to the Investment Company Act because of monetary policy considerations. ${ }^{38}$ In section 2 below, we will use this episode of financial market regulation to clarify further the role of the monetary authority in protecting banks deposit franchise.

Another revision of the Banking Act occurred in 1995 and led to changes in the rules on consolidation and large-credits. A major innovation was brought about by the sixth amendment to the Banking Act in 1998 that implemented three European Directives: the Investment Services Directive, the Capital Adequacy Directive, and the so called Post-BCCI Directive. As a consequence of the 1998 reform, like in other European Countries, investment firms are now supervised according to the same rules as credit institutions. Also the concept of the trading book was introduced and Principle I was changed accordingly. ${ }^{39}$ Banks are now allowed to use their own internal models to assess their risk position with respect to the trading book. In 1998 the Directive on Depositor Guarantee and Investor Protection was implemented. A statutory system compensating depositors in the event of bank default was established that complements the already existing group specific schemes. ${ }^{40}$ In 1999 the FBSO changed its internal structure and, among other things, established a new division concerned with "complex groups", that is with large international financial conglomerates. In

\footnotetext{
${ }^{37}$ While the implementation of this directive in 1993 did not materially change Principle I, the question of what types of equity capital German authorities would allow to consider as "liable capital" was hotly debated.

${ }^{38}$ This point is also emphasized by Saunders/Walter (1994).

${ }^{39}$ Tier 3 capital was defined and an institution's own funds were introduced as an adjustment to its liable capital.

${ }^{40} \mathrm{~A}$ discussion of the private deposit insurance scheme in Germany is provided further below.
} 
2002 a major reform in financial market supervision occurred, when a new integrated financial services supervising authority was established that comprises the formerly separated supervisory offices for banking, insurance and securities trading. ${ }^{41}$ Obviously the Ministry of Finance has thus made a serious attempt to track the organizational complexity of today's financial services industry.

Table 1 summarizes the most important events in German bank regulation since World War II.

\section{<Table 1 around here>}

With respect to the fundamental structure of the regulatory regime and the driving forces for its adjustments over time, the following is worth emphasizing and will be discussed in more depth in section 2:

Banking regulation in Germany, at least since World War II, has rested on two strong pillars: licensing and supervision on the one hand and capital requirements on the other. Limits on banking activities, portfolio composition or lending activities, ceilings on deposit interest rates, or restrictions on bank branching in contrast have either not played a significant role from the outset, or were abolished much earlier than in other countries. In some sense these observations seem to contradict the notion of particularly anti-competitive bank regulation in Germany. Although the regulatory frame was relatively stable until the early 1990s, amendments to the Banking Act before 1990 were triggered primarily by problems of single institutions. Reforms that were enacted after 1990 in contrast were motivated in the first instance by the necessity to transpose EU directives into German law. With respect to identifying key players in the regulatory arena, it is worth noticing that on several occasions the Bundesbank prevented the introduction of securitized money market instruments (money market funds, DM-denominated CDs) for monetary policy reasons. Furthermore, it effectively deterred entry by foreign banks in DM-denominated bond underwriting activity.

\footnotetext{
${ }^{41}$ The role of the Bundesbank in banking supervision has formally remained unaltered by this restructuring.
} 
1.4 Market structure and conduct: empirical evidence on the competitiveness of German banking

In the introduction it was stated that German banking in the past was often considered as stable but not very competitive. If assessments of the stability of banking are based on the number of failures and the occurrence of systemic banking crises, the notion of the relative stability of German banking since World War II cannot easily be rejected. By comparison, the empirical evidence on the degree of competition among German banks is somewhat more ambiguous.

\section{Market structure and industry concentration in a universal banking system}

An important aspect of the German tradition of bank structure and regulation is that regulators impose only few restrictions on the range of services banks are allowed to offer to their customers. It seems fair to say that Germany is perceived to be the prototype of a universal banking system. The most direct tool for regulating the structure of banking and financial services, namely the centerpiece of all banking legislation, therefore lies in the definition of what constitutes a bank. This definition is crucial as it defines the scope of activities and products subject to regulation. And on the other hand, it also implicitly defines a group of non-bank suppliers of financial services that remain unregulated or are subject to some other form of public intervention. ${ }^{42}$ The German Banking Act defines a credit institution as an enterprise commercially active in at least one of twelve fields of business, which include deposit taking, loan granting, discounting of bills of exchange, investment fund business, securities underwriting and the like. ${ }^{43}$ Edwards/Fischer (1994) note that "[...] the legal definition of banking business is so broad that most financial institutions are, by definition, banks “. Only banks' insurance activities, mortgage banking and activities of building societies require legally separate subsidiaries.

However, data compiled by Barth et al. (2001) shows that from 1999 onwards universal banking was common in EU countries. One of their indices summarizes information about the restrictiveness of bank participation in specific financial services activities (securities, insurance and real estate) and about whether banks are allowed to own non-financial firms.

\footnotetext{
${ }^{42}$ See also Barth et al. (2001).

${ }^{43}$ Besides, the Banking Act also defines a group of financial services institutions (portfolio management, investment trading, own-account trading) and financial enterprises (leasing, consulting (M\&A etc.)).
} 
An index value of 1 indicates that no restrictions are imposed on banks, whereas a value of 4 would indicate that all activities in these areas are prohibited. ${ }^{44}$ While Germany is among the countries with a low index (1.25), the average index value for EU countries is 1.82, which is significantly lower than in the rest of the world ( $1 \%$ level of significance). ${ }^{45}$ The world wide average of the restrictiveness index is 2.5. It is 2.3 for European non-EU countries, 2.9 for African countries, 2.5 for American Countries and 2.7 for Asian countries in the Barth et al. (2002) dataset. Continental European banking markets in general now seem to be characterized by a universal banking approach. However Berger et al. (2001) suspect that the Single Market Program (SMP), and the rule of mutual recognition in particular, has made universal banking the norm in the EU because remaining restrictions at the national level might put domestic banks at a disadvantage. ${ }^{46}$ If this notion were true, for some observers universal banking might appear as the best practice benchmark and competition would lead to strong convergence towards unrestricted bank activities.

Theoretically there seem to be several reasons why universal banks could be more efficient than specialized banking institutions that are restricted in the scope of their activities. ${ }^{47}$ Rajan's (1996) discussion, however, should make us somewhat cautious here: His argument points to the relevance of the legal and financial framework within which universal banks are allowed to operate. Following his argument, in a financial system that is fairly competitive, where a full range of financial services providers are allowed to operate and where there are meaningful disclosure requirements as well as political checks and balances and a working regulatory framework, universal banking could hardly be harmful to the economy. In such a framework competition decides whether universal banking or more specialized financial institutions will be the most efficient vehicles for providing firms and households with financial services. But in a country where these requirements are not met, the historical

\footnotetext{
${ }^{44}$ In computing this index Barth et al. (2001) use detailed information on bank regulation in a large cross-section of countries. Barth et al. (2001) proceed as follows. For every country in their dataset they rank the degree of restrictiveness imposed on banks when entering a certain line of activity. They consider securities activities, insurance, and real estate activities. Further they look for restrictions on the ability of banks to own and control firms. For all these activities they assign values ranging from 1 (=unrestricted) to 4 (=prohibited). The indices mentioned in the text above are just the average of these ranks.

${ }^{45}$ These figures are based on our own computations using the Barth et al. (2001) data base. Access to their data is gratefully acknowledged.

${ }^{46}$ Unfortunately they were not able to exactly follow the development of regulations on banks' activities in EMU countries. A partial sketch of these developments is provided by OECD (1992), pp. 51-54 (Table 4).

${ }^{47}$ These range from economies of scope to the more efficient use of customer specific information and finally to arguments involving the diversification of business risk. See Rajan (1996) for an overview and Vander Vennet (2002) for empirical evidence in favor of this hypothesis.
} 
predominance of a few large universal banks might have seriously hindered the emergence of securities markets, financial innovations, and more specialized suppliers of financial services. ${ }^{48}$ As yet these idiosyncrasies of universal banking systems are not well understood. ${ }^{49}$ This is especially true for an analysis of the competitive effects of universal banking and its likely repercussions in the regulatory framework. Although our ability to analyze questions of this type is limited, we will proceed by describing the competitive structure of the German universal banking system in order to provide a first step towards a better understanding.

Hackethal (2003) gives a detailed description of the structure of the banking market in Germany highlighting the role of private, public and co-operative banks. For a basic understanding of this so-called three-pillar system we refer the reader to his contribution to this volume, which we take as a starting point for our discussion in the remainder of this section.

In light of standard oligopoly theory, measures of market structure and especially indices of bank concentration might serve as first indicators for the degree of competitiveness. This is exactly why indices of market concentration, for example concentration ratios and the Herfindahl index, play such an important role in almost all recent assessments of US and European banking markets. They are also widely used in empirical work. Data presented in the literature, however, does not draw a clear and reliable picture. For example, figures for the 3-firm concentration ratio CR3, the combined market share of the three largest institutions, for the German banking market range from $89.5 \%$ in Allen/Gale (2000) to $27 \%$ in Cetorelli/Gambera (2001) and even to a low value of less than $17 \%$ in Danthine et al. (1999). While a 3-firm concentration ratio of around $90 \%$ would lead us to conclude that Germany is among the most highly concentrated banking markets in the world, a figure of less than $17 \%$ would indicate exactly the opposite and make Germany one of the least concentrated banking industries world wide. What is the underlying problem in interpreting these measures of market concentration? Although this question is almost impossible to answer precisely, as we

\footnotetext{
${ }^{48}$ Market power as well as political power and regulatory capture might be responsible for such a negative effect on financial development. See Rajan (1996) and also Barth et al. (2002). Similarly Boot/Thakor (1997) offer several reasons why stand-alone banks might be at a disadvantage in universal banking systems that are not based on economic efficiency. Obviously questions of this type are of central importance for any assessment of the financial system in Germany and its historical performance. See for instance the contribution by Franzke et al. (2003) for an in-depth analysis. Although such a discussion goes far beyond the scope of this chapter, it might nevertheless provide some guidance for a discussion of bank regulation and competition. Firstly, an assessment of the regulatory framework within which universal banks are forced to operate, might turn out to be a useful intermediate step towards a better understanding of universal banking. Secondly, it is important to keep in mind that "allowing" universal banking need not necessarily lead to actually "observing" universal banking.

${ }^{49}$ See also Rajan (1996) for such an assessment.
} 
see it, more attention should be devoted to traditional questions related to the delineation of the relevant market in terms of geographic reach as well as in terms of the set of relevant competitors. For example, it seems to be widely accepted that retail banking markets are local in nature. ${ }^{50}$ Markets for investment banking services in contrast seem to have grown beyond national boundaries and today are perceived to be of almost global dimension. Furthermore, while the majority of German banks is active in the retail segment, only a few of them offer investment banking services. ${ }^{51}$ Most of these retail banks conduct their business in narrowly defined regional markets as they belong to either the co-operative or the public banking sector. Since these banking institutions do not invade each others' regional markets, withingroup competition is of only minor importance. Finally, as pointed out by Hackethal (2003) competition in German financial services might be described as competition among groups of financial conglomerates. Besides the few big banks the co-operative as well as the public banking sector could also be viewed as one large competitor that offers almost all types of financial services. Whether the group character of competition softens competitive pressure or even intensifies it, is an open but extremely important question.

\section{Retail banking}

Let us turn to retail markets first. Table 2 contains Herfindahl indices for German administrative regions called Landkreise for the years 1996, 1998 and 2000. These regions might be a useful approximation for local banking markets relevant to retail banking in Germany. Because market share data for banks is generally not available at this level of disaggregation, branching data was used instead. ${ }^{52} \mathrm{MS}_{\mathrm{i}, \mathrm{j}}$ denotes bank i's market share in local market $\mathrm{j}$. We approximated $\mathrm{MS}_{\mathrm{i}, \mathrm{j}}$ by the number of branches that bank $\mathrm{i}$ operates in $\mathrm{j}$ divided by the total number of bank branches operated in market $\mathrm{j}$. Individual bank market shares in a given administrative region were squared and summed.

\section{$<$ Table 2 around here $>$}

\footnotetext{
${ }^{50}$ See Amel et al. (2001) or Cruickshank (2001), chapter 5.

${ }^{51}$ If the retail market were indeed national in scope and all banks would compete in retail services, then a CR3 around $12 \%$ to $13 \%$ would be a reliable estimate for the year 2000 . The Herfindahl based on balance sheet total would then be around 0.015. See Bundesbank (2001).

${ }^{52}$ As Fischer (2001) shows for US Metropolitian Statistical Areas, Herfindahl indices based on branching data provide a reasonable approximation of the more common Herfindahl indices based on deposit market shares.
} 
Although the figures in table 2 are not directly comparable with data from other countries, three conclusions can be drawn ${ }^{53}$. Firstly, local banking markets in eastern Germany are much more concentrated than their western counterparts. There are structural differences between eastern and western markets which might account for the differences in concentration. For example during the 1990s per capita income was lower and default rates were higher in the eastern part of the country. ${ }^{54}$ It might nevertheless be interesting to note that with German reunification in 1990 public savings banks and credit-co-operatives were inherited from the former German Democratic Republic. Although these institutions had to be reshaped in several dimensions, market entry in the sense of opening branches was primarily observed with private banks. Secondly and unlike the US, there seems to be no clear-cut rural-urban pattern. ${ }^{55}$ One reason is the large number of relatively small co-operative banks in rural areas which lead to more fragmented market structures. Thirdly, during the 1996 to 2000 period, the process of industry consolidation was much more pronounced in rural areas (especially in the eastern part of the country), and this might also be seen as a consequence of the fragmented structure of co-operative banks in rural areas. As already mentioned above, the retail market is quite fragmented as the public and co-operative banks among themselves do not in principle invade each others' regional markets. Table 3 provides an initial basic impression which further illustrates the typical structure of a local banking market in Germany. In order to enable a better comparison we took into account all 83 German cities with more than 100,000 inhabitants. As a sub-sample of all markets considered in table 9, these densely populated city areas are relatively homogeneous and might well serve as useful approximations for local banking markets.

\section{$<$ Table 3 around here $>$}

On average there are 25 banks present in these local markets. In 63 of the 83 cities considered there is only one savings bank present, whereas there are on average 6 co-operative banks and 17 private banks. This reinforces the widely held notion that the principle of market demarcation is almost perfect among the local savings banks. Savings banks are strictly tied

\footnotetext{
${ }^{53}$ Fischer (2001) computes Herfindahl indices based on branching data for 212 Metropolitan Statistical Areas in the US. The average Herfindahl for these local US markets is 0,1135 and is thus considerably lower than the 0,2 for densely populated areas in western Germany.

${ }^{54}$ A two-stage game of banking competition comprising an entry stage where banks decide whether to conduct deposit and loan business in a certain local market and in the second stage compete in prices or quantities, would normally predict that less banks enter whenever borrower default risk is higher or households are less wealthy.

${ }^{55}$ In the US, for example, the rural county markets show significantly higher bank concentration than the more urban MSA markets.
} 
to the local market, which is identical to the jurisdiction of the municipalities that act as their guarantors. Market areas of co-operative banks in contrast show much more regional overlap. On average $40 \%$ of all branches in these local markets are operated by savings banks and $22 \%$ are operated by co-operative banks. Measured this way, the market share of the four large private banks is approximately $21 \%$ in these 83 markets.

Looking at local banking markets as the relevant market in retail banking business thus reveals that the large private banking institutions,i.e. Deutsche Bank, Dresdner Bank, Hypovereinsbank and Commerzbank, which are often perceived as being the most powerful and dominant players in German financial services, are better described as fringe players in many local markets (the average share of the branch network in the 83 markets considered amounted to 7\% for Deutsche Bank, 5\% for Dresdner Bank, 5\% for Commerzbank and 3\% for Hypovereinsbank), whereas savings banks and co-operative banks seem to dominate the retail market. In all 83 city markets considered, the largest supplier in terms of branch networks is the local savings bank. Figure 1 displays average concentration ratios from CR1 to $\mathrm{CR} 10$ for cities with populations above 100,000 . On average the local savings bank operates $40 \%$ of all branches (ranging from $20 \%$ to $60 \%$ within our sample of densely populated cities); the next largest banks all operate considerably smaller branch networks.

\section{$<$ Figure 1 around here $>$}

The important issue here is how these structural aspects affect competition in retail banking. In addition to the question of how German banking compares to its European peers, there might also be a specific interest in intra-industry studies of concentration and price. ${ }^{56}$ Retail banking markets are particularly well suited to this type of analysis because there is strong evidence - anecdotal as well as analytical - that markets can be separated by location. Moreover, studies using data from only one national market might lead to more accurate conclusions concerning the influence of market structure on price because omitted variables with respect to the legal and regulatory environment are less likely to play a role. As already mentioned above, surveys among households and small enterprises in the US conducted by the Federal Reserve Board offer convincing evidence that loan and deposit customers shop for banking services in rather narrowly defined markets. In most empirical work in the US so-

\footnotetext{
${ }^{56}$ In his survey on structure-performance studies Schmalensee (1989) concludes "In cross-section comparisons involving markets in the same industry, seller concentration is positively related to the level of price" and Since studies of price have fewer obvious weaknesses than studies of profitability [this] seems to provide the best evidence in support of the concentration-collusion hypothesis”, see Schmalensee (1989), p. 988.
} 
called metropolitan statistical areas or counties serve to approximate these local markets. Studies such as Berger/Hannan (1989), Neuberger/Zimmermann (1990) or Neumark/Sharpe (1992) have all found strong evidence in favor of the concentration price relationship at the intra-industry level. For Europe to date only a few such studies exist. Fischer (2001) analyzes this relationship for local retail banking markets in Germany from 1992 to 1995. Since market share data in deposit and loan markets is not available, he computes measures of supplier concentration based on branching information. For most bank products considered, the study finds a significant concentration price correlation that points to the exercise of market power in more concentrated markets. Deposit rates, especially those on time deposits and savings deposits, are lower in more concentrated markets (i.e. the margins earned by banks are higher). Rates on loans to small firms are significantly higher in these markets. As a further illustration, table 4 displays results of concentration-price regressions using data from Fischer (2001). ${ }^{57}$ Table 4 contains results of pooled regressions for three specific bank products for the 1992 to 1995 period using end-of-quarter observations on discount loans to small borrowers (with loan volumes below $€ 50.000$ ), savings deposits and time deposits with maturities between one and three month. ${ }^{58}$ The dependent variable is the difference between the product interest rate and the three-month money market rate (FIBOR). ${ }^{59}$ Control variables are all observed at the local market level; as in other studies that estimate reduced form price equations, the coefficients of most of the control variables are difficult to interpret. ${ }^{60}$ However, confirming empirical results from other countries and in line with standard oligopoly theory, the Herfindahl index of local market concentration seems to be positively related to gross margins earned by German banks and is significant in two regressions (savings deposits and discount loans). ${ }^{61}$

\section{$<$ Table 4 around here $>$}

\footnotetext{
${ }^{57}$ The specification used here, however, is somewhat different from Fischer's (2001).

${ }^{58}$ For further results and some other specifications and estimation techniques see Fischer (2001).

${ }^{59}$ For the two deposit products the margin is computed as "money market rate minus deposit rate"; the loan margin is "loan rate minus money market rate".

${ }^{60}$ See Berger/Hannan (1989), Neuberger/Zimmerman (1990) or Borenstein (1989) for similar problems.

${ }^{61}$ Further evidence on the concentration-price relationship in Germany comes from an empirical analysis of the price effects of local bank mergers. Mergers that lead to stronger increases in local bank concentration also show stronger subsequent price effects to the disadvantage of loan and deposit customers; see Fischer (2001).
} 
To derive comparable structural measures of the market for investment banking services is somewhat more difficult. What is the geographic scope of this market? Should, for example, in underwriting corporate bonds and equity a global approach be taken and should these issues be considered with respect to European or only to German entities? For the following analysis we considered issues involving German entities only, thus allowing a more focused interpretation of the results. Table 5 shows Herfindahl indices for banks acting as lead underwriter in IPOs in Germany during the 1990 to 2000 period. $^{62}$

\section{$<$ Table 5 around here $>$}

As can be seen from table 5, the market for lead underwriting services was highly concentrated at the beginning of the 1990s. Only few IPOs were brought to the market and the large German banks (Deutsche Bank, Dresdner Bank and Commerzbank) dominated in equity underwriting. Of the Landesbanks, only WestLB had a noticeable market share. During the 1990s ,however, the development towards strong market fragmentation began. ${ }^{63}$ As the IPO market grew considerably, more and more banks entered and the market share of foreign banks especially increased dramatically. Comparable market structure data for bond markets is harder to find. As an example, therefore, table 6 lists the top ten bookrunners of Eurodenominated bonds issued or guaranteed by German entities in 2001.

\section{$<$ Table 6 around here $>$}

A similar picture emerges here. While Deutsche Bank and Dresdner Bank's investment banking subsidiaries take the lead positions and Commerzbank ranks No. 8 in bond underwriting with German issuers, no other German bank is among the top ten underwriters. Again US investment banks have gained significant market shares in recent years. In M\&A advisory mandates related to Germany a similar picture emerges as only Deutsche Bank and Dresdner Bank play a role of any importance in these transactions (for the sake of brevity, we do not report market share data here). Overall, in investment banking services the following picture emerges. Investment banking business - even with German corporate customers - was

\footnotetext{
${ }^{62}$ For more evidence and an in-depth discussion on IPOs in Germany see Franzke et al. (2003).

${ }^{63}$ Market fragmentation as a response to market growth is a standard result in IO; see Sutton (1991) for further details.
} 
heavily invaded by US investment banks during the 1990s. Building on their skill and reputation, these banks have recently increased their capacities to a considerable extent all over Europe. Apart from large players like Deutsche and Dresdner, whose strategy is explicitly orientated towards investment banking, most German banks by comparison have difficulty in establishing a significant role for themselves in this market segment. To date even the Landesbanks are of minor importance. Although often deemed to be the prototype of a universal banking system, a closer look at banks in Germany reveals that there is much more separation of business activity among banking institutions. Historically investment banking has not been a significant area of business for most German banks. Moreover, many of them are doing business in rather narrowly defined local markets. Only a few large banks are supraregional in scope or offer true investment banking services. Another peculiarity of the German case is that competition is among integrated groups of financial services providers rather than among single banking institutions. While these structural peculiarities are quite obvious, their influence on market outcomes and economic performance is by no means clear.

\section{Competitiveness in German banking}

To assess the competitiveness of a market, the empirical industrial organization (IO) approach can be applied as it offers a range of techniques from traditional structure-performance studies to the more recently developed new empirical IO methods. ${ }^{64}$ In the US questions related to the industrial organization of banking have always been of great interest to both academics as well as bank regulators. By comparison in Europe there is not yet much empirical evidence on the issue, despite the widespread belief that considerable market power is exercised by banks. Given the purpose of this section two questions seem to be of importance. Firstly, what can be said about the competitiveness of German banking when compared to other countries, most importantly its European peers? Secondly, are there any differences in terms of conduct between banking groups (co-operative, public, private) within the German financial system?

Courvoisier/Gropp (2002) use the more traditional structure-performance approach toanalyze the relationship between bank retail margins and measures of national industry concentration for the 1993 to 1999 period. Their study comprising observations from 10 European countries finds a statistically and economically significant correlation between margins and product specific measures of industry concentration. Given that their estimate of a national German Herfindahl index is low and Germany is the least concentrated market in the

\footnotetext{
${ }^{64}$ See Bresnahan (1989) for an overview.
} 
Courvoisier/Gropp (2002) data set, a possible interpretation of their results is that Germany is one of the most competitive banking markets in Europe and margins in deposit and loan markets are low in international comparison ${ }^{65}$.

Several empirical studies apply the methodology proposed by Panzar/Rosse (1987) estimating reduced form revenue functions and using the sum of estimated factor price elasticities - the $\mathrm{H}$-statistic - as an indicator of competitiveness. According to Panzar/Rosse (1987) the Hstatistic is 1 in the case of perfect competition and negative in the case of monopoly behavior, intermediate values refer to monopolistic competition. Hempell (2002) uses a large panel data set covering almost all banks reporting to the Bundesbank for its monthly banking statistics. Like Lang (1997), who uses a subset of German private, co-operative and public savings banks, her analysis focuses on the differences between German banking groups and the differences over time. Bikker/Groeneveld (1998), De Bandt/Davies (1998) and Molyneux et al. (1994) in contrast analyze competition in a cross-section of European countries using Fitch IBCA's data bank. All these studies find intermediate values for the H-statistic for German banks, which do not allow for a very precise interpretation of the mode of industry conduct. In Hempell (2002) and Lang (1997) and De Bandt/Davies (1998) H-statistics are larger (indicating more competitive behavior) for larger banks than for smaller ones and for private banks compared to savings banks and credit co-operatives. A possible interpretation is that smaller banks, savings banks as well credit co-operatives, exercise market power due to their strong competitive position in local retail markets and the type of spatial differentiation that comes with it. ${ }^{66}$ From those three studies that use cross-country data it is hard to judge how Germany compares to other European countries. With only a few exceptions, across Europe all estimated $\mathrm{H}$-statistics are between 0 and 1, indicating monopolistic competition; no further comment can be made. However, lack of robustness across specifications or time, large standard errors and most notably problems in interpreting intermediate values of $\mathrm{H}$ render pairwise comparisons inconclusive. For example, in Bikker and Groeneveld's study almost all country-specific estimates are well above 0.75 with only a few that are indistinguishable from 1 (perfect competition).

\footnotetext{
${ }^{65}$ We have already noted the large differences in measures of German bank market concentration to be found in the literature.

${ }^{66}$ However it must be noted that systematic differences in the maturity structure of loans and deposits between banking groups might also contribute to this result as they obviously influence measured factor price elasticities.
} 
In empirical IO a widely accepted measure of the degree of market power, or alternatively an inverse measure of competition, is the Lerner Index $L$. With $P$ for price, $M C$ for marginal cost and $\eta(p)$ denoting the price elasticity of demand, the Lerner Index computes as

$$
L=\frac{P-M C}{P} \eta(p)
$$

As an alternative to the Rosse/Panzar methodology, one could as well attempt to measure this index more directly. A quick and simplistic method uses accounting data on revenues or price data and imposes restrictive assumptions with respect to marginal cost. ${ }^{67}$ A more sophisticated alternative, however, tries to estimate the Lerner index econometrically from structural models of oligopoly behavior based on conjectural variations. ${ }^{68}$ There are several applications of this methodology in banking markets. ${ }^{69}$ Neven/Röller (1999) for example, investigate industry conduct in European loan markets and find significant exercise of market power in corporate loan and household mortgage markets. Given their estimate of the elasticity-adjusted Lerner index close to 1, they cannot reject the hypothesis of collusive conduct in Europe. However, their data and technique do not allow for the separate estimation of conduct parameters for the countries that comprise their sample and it is thus not possible to compare Germany to its European peers.

Angelini/Cetorelli (1999) and Ribon/Yosha (1999) analyze the effect of banking deregulation on industry conduct in Italy and Israel respectively. Both studies find significant shifts towards more competitive industry conduct throughout the 1990s. Fischer/Hempell (2003) employ a methodology quite similar to Angelini/Cetorelli's (1998) cross-sectional study and investigate industry conduct in Germany for the 1994 to 2001 period for a sample which includes almost all German banks that report their P\&L accounts to the Bundesbank. Estimated Lerner indices for implied prices of compound banking services, including both interest and non-interest income, are displayed in figure 2 below for all banks in the sample and for banks from western Germany separately. ${ }^{70}$

\footnotetext{
${ }^{67}$ For examples see Domowitz et al. (1996) for manufacturing industries, or Gual/Neven (1993) using price data for European banking.

${ }^{68}$ See Bresnahan (1989) for an overview and Genesove/Mullin (1998) for an application that provides evidence in favour of the accuracy of the methodology.

${ }^{69}$ See, for example, Neven/Röller (1999), Shaffer (1993) for Canada, Spiller/Favero (1984) for Uruguay, Ribon/Yosha (1999) for Israel or Angelini/Cetorelli (1999) for Italy.

${ }^{70}$ The estimated model consists of a price equation derived from the first-order condition of a profit maximising oligopolist in a static conjectural variation equilibrium and a cost function of the translog functional form. The
} 


\section{$<$ Figure 2 around here $>$}

The Lerner indices in Figure 2 are not adjusted for the elasticity of demand for the compound banking service and thus should be interpreted with some caution. ${ }^{71}$ Also, the use of accounting data in Fischer/Hempell (2003) raises some specific problems. For example, as their measure of price is derived from banks' fee income and interest income figures, unexpected losses due to borrower distress bias the measure of bank market power downward. ${ }^{72}$ Furthermore, the maturity structure of a loan portfolio might seriously affect this measure of price. $^{73}$

Taking all these difficulties into account, the Lerner indices reported by Fischer/Hempell (2003) seem to be moderate and are well below 0.10 during the sample period. There is a marked decline in the Lerner indices both for the full sample of German banks and the western German sub-sample, indicating an intensification of competitive rivalry throughout the 1990s. Moreover, higher Lerner indices for the sub-sample of banks from the western part of the country may be interpreted as preliminary evidence of less market power exercised by eastern German banks.

These figures thus do indeed support the notion that German banking has been quite competitive during the second half of the 1990s. Whether a similar conclusion could also be drawn for the 1970s and 1980s, remains an open question. Obviously, cautioun should be exercised in drawing strong conclusions from the few studies that are currently available and it is wise to be well aware of the fact that the empirical estimation of market power and competitiveness entails many methodological problems. Summing up, however, it can be concluded that the existing empirical evidence does not lend much support to the widely held notion of significant market power exercised by German banks.

cost function includes three factor prices as explanatory variables. The system was estimated with 3 SLS instrumental variables procedures. See Fischer/Hempell (2003).

\footnotetext{
${ }^{71}$ However, most econometric estimates of, for example the interest rate elasticity of loan demand yield values well below 1. See Ribon/Yosha (1999) for one such example.

72 There is little dispute that the frequency of such events has steadily increased during their sample period. Furthermore, it must be noted, that as an ex post measure of market power, these Lerner indices could also be negative for some sub-periods.

${ }^{73}$ See Hempell (2002) for further discussions.
} 


\section{A closer look - selected issues in German bank regulation}

\subsection{Introduction}

We first of all review an episode of German financial market regulation - the introduction of money market mutual funds in 1994 - in order to throw more light on the role of the Bundesbank and of monetary policy considerations. Next we focus on the building blocks of modern prudential regulation, i.e capital requirements, the supervisory process and deposit insurance. While the first of these issues is now fully harmonized internationally, the other two still display important peculiarities in Germany. In particular in supervision and deposit insurance, aspects of industry self-regulation still seem to play a noticeable role.

\subsection{Money market funds, bank deposits, and the role of the Bundesbank}

One of the relationships that seemed to have played an important role in the design of financial market regulation in Germany stems from the natural conflict of interest between bank regulation and monetary policy. Since World War II and owing to the trauma of two hyperinflations, there has been a strong desire on the part of German central bankers to pursue their anti-inflationary policy independently not only of political interference but also of the short term effects that it might have on financial markets and on real economic activity.

From a very general perspective, every central bank would prefer higher banking industry profits to lower ones, simply because higher profits lower the probability of bank failures and thus of financial instability. ${ }^{74}$ Given that financial stability is an important prerequisite for the independent conduct of monetary policy, a central bank might, in one way or another, influence matters in favor of incumbent banks' profitability. The argument that applies to the Bundesbank, however, is somewhat more specific and based on the viability of monetary targeting on the one hand and a natural conflict of interest between monetary and regulatory objectives on the other. This latter point - often overlooked - is made precisely in Goodhard/Schoenmaker (1993) who note: "It is the German tradition which exhibits the greatest concern about conflicts of interest, and the greatest desire for separation of

\footnotetext{
${ }^{74}$ See Cukierman (1993) for a discussion.
} 
responsibilities; yet it is the German system, dominated by an oligopoly of enormously powerful universal banks, with relatively underdeveloped, competitive wholesale financial markets, in which such 'conflicts'of interest will be least bothersome". ${ }^{75}$ The Bundesbank has always played a significant role in the regulatory process. ${ }^{76}$ Besides its involvement in bank supervision, the central bank has had a powerful say in almost every discussion about financial market reform. ${ }^{77}$ As an example, the Bundesbank always strongly opposed the introduction of securitized money market instruments issued either by the government or by private entities. The Bundesbank argued that these instruments would affect the accuracy and empirical basis of monetary targeting as well as the effectiveness of reserve requirements as an instrument of its monetary policy. Furthermore, the Bundesbank repeatedly maintained that such instruments would introduce "short-termism" into the financial sector. In a Monthly Report in 1997 this was stated as follows: "If a major part of credit terms is geared to shortterm interest rates, however, the impact of the central bank's interest rate policy measures on the real economy increases, as does the risk of conflicts of interest $"{ }^{78}$ By preventing these short-term instruments from being marketed, however, the Bundesbank effectively protected the deposit franchise of German banks.

A nice example that further illustrates this point is the struggle for the introduction of money market mutual funds at the beginning of the 1990s. In 1988 the state of Lower Saxony proposed changing the law on investment companies and allowing money market mutual funds to operate. Until then, the Investment Company Act stipulated that funds were not allowed to invest in short term instruments with maturity below one year. From the beginning of the discussion on money market funds, the political side, i.e.all political parties at the federal as well as at the state level, had a strong preference in favor of the proposed reform. The Bundesbank strongly opposed. It is striking that this veto was enough to stop any further legislative initiative for a couple of years. As in many previous instances, the federal government in particular regarded the Bundesbank's veto as imperative. But in January 1992 the Ministry of Finance surprisingly launched another attempt to allow market funds to

\footnotetext{
${ }^{75}$ Goodhart/Schoenmaker (1993) provide a nice description of the manifestation of this conflict of interest.

${ }^{76}$ See also Franke (2001).

${ }^{77}$ According to the German Banking Act, participation of the Bundesbank in the regulatory process is limited and, depending on the specific case considered, ranges from its participation in official hearings to the requirement that it explicitly agrees to regulatory actions undertaken by the Federal Banking Supervisory Office (FBSO). Especially in the legislative process the Bundesbank only acts as an advisor to the Federal Government and occasionally expresses its opinion. In reality, however, its influence has always been much stronger and was well beyond what could be derived simply from its legal status.
}

${ }^{78}$ See Deutsche Bundesbank (1997). 
operate in Germany. In its outline for financial market reform, the Ministry explicitly proposed changing the law on investment companies accordingly. ${ }^{79}$ The Bundesbank responded almost immediately and couple of weeks later it declared money market mutual funds as "unwelcome" and refused all further attempts to introduce these instruments. The Ministry of Finance, in reaction, then withdrew its proposal and stated that it did not intend to allow money market mutual funds in the near future. In 1994, however, harmonization activities at the European level forced the Bundesbank to change its position. European negotiations on the so called OGAW Directive made it clear that national resistance against money market funds could no longer be sustained. However, when the Bundesbank's decision to put aside its reservations against money market funds became public, this came as a real surprise to the market. Upon announcement of the Bundesbank's retreat, German banks experienced significantly negative stock price reactions. Table 7 displays the authors' own estimates of cumulative abnormal returns for three bank portfolios around the announcement date. $^{80}$

\section{$<$ Table 7 around here $>$}

CARs in table 7 indicate that the three large banks (Deutsche Bank, Dresdner Bank and Commerzbank), which comprise the large bank portfolio (right column of table 7) experienced more negative abnormal returns compared to smaller banks. This might be due to "cannibalization" effects, since these banks have large investment companies as their subsidiaries, who were among the first to offer money market funds to their customers and thus created in-house competition for depositors' funds. An examination of the abnormal returns of single banks indicates that negative stock price reactions seem to be related to the share of savings deposits in a bank's financial structure (not shown here). ${ }^{81}$ Although only based on a sample of thirteen banks whose stock traded on an exchange at that time, these results could be seen as an indication of more competitive pricing behavior in bank deposit markets following the introduction of money market mutual funds. Some supporting evidence

\footnotetext{
${ }^{79}$ See Bundesfinanzministerium (1992).

${ }^{80}$ Unfortunately the announcement of the Bundesbank's retreat is contaminated by a downward change in the discount rate and Lombard rate, which occurred the same day. This contamination however is most likely to lead to an upward bias of our estimate of a negative stock price reaction. Kaen et al. (1997) for example show that during the 1987 to 1993 period, a downward change in either the discount rate or the Lombard rate in every single case led to positive price reactions of banks' stock. Taking this into account, the actual stock price reaction upon announcement of the Bundesbank decision with respect to money market funds might have been even more negative than those documented in Table 7.

${ }^{81}$ This is interesting because after the introduction of money market funds especially Savings banks and cooperative banks offered new products in the field of savings deposits, which significantly increased the interest paid on these accounts. See also Bundesbank (1997).
} 
for this hypothesis can further be found in banks' pricing behavior following the licensing of the first of those funds in August 1994. Bank deposit margins, defined as the difference between money market rates and rates on time and savings deposits of equal maturity, dropped significantly as shown in figure 3. This figure displays an equally weighted index of gross deposit margins comprising different types of savings and time deposit products (the line in figure 3). It also shows the number of money market mutual funds that were licensed by the FBSO and subsequently offered to the public (the bars in figure 3 ). It might have been the introduction of money market funds that led to a significant decline in bank deposit profitability.

\section{$<$ Figure 3 around here $>$}

This story about the introduction of money market mutual funds covers just one episode of financial market regulation in Germany. ${ }^{82}$ It might nevertheless be seen as comprising two important aspects that have been of more general meaning in the past. On the one hand, there is the strong role of the Bundesbank and monetary policy considerations which, intentionally or otherwise, might have had the effect of protecting banks' oligopolistic rents. On the other hand, there is the indisputable influence of harmonization initiatives at the European level that exerted considerable pressure on policymakers in Germany.

\subsection{Capital requirements and the supervisory process}

\section{Capital requirements}

As laid out in section 1.3 above, most amendments to bank capital regulation (Principle I and the respective sections of the Banking Act) during the 1990s served to transpose European Directives into the domestic legal framework. As these developments are well documented in the international literature, and capital requirements can now be seen as the predominant and most harmonized of all bank regulations, we will forego further descriptions here.

Nevertheless several remarks are in order. From a very basic and rather mechanical perspective, when a bank's asset risk is assumed to be exogenous, capital serves as a buffer stock against losses resulting from risky assets and thus reduces the risk of bank failure. ${ }^{83}$ Tightening capital standards therefore forces banks to either raise new equity, boost retained

\footnotetext{
${ }^{83}$ Capital requirements might as well effectively limit the amount of risk a bank can assume.
} 
earnings or alternatively to cut back on investing in those risky assets (corporate loans for example).

However, as Rochet (1999) points out, this perspective is too simplistic, as it does not take into account that bankers, as a response to mandatory capital requirements, might be induced to systematically reallocate their portfolios. ${ }^{84}$ In the introduction to this section it was mentioned that asset-substitution type risk-shifting incentives are perceived to be an especially virulent problem in banking. The high leverage of limited liability banks creates incentives to take excessively risky positions. Flat premium deposit insurance that undermines deposit market discipline might even accentuate this problem. It is generally perceived that a primary objective of bank regulation is to deal with these unwanted incentives of bankers. Bank capital regulation not only serves to reduce the risk of bank failure directly, but is also aimed at making these incentives less severe. This is why the more indirect effects of capital regulation have to be carefully assessed. Whether capital requirements trigger perverse incentives in the sense that such reallocations lead banks to invest in even riskier assets, is still an open question and theoretical work yields ambiguous results. While some work supports the traditional notion that more onerous capital requirements lead banks to reduce their risk-taking ${ }^{85}$, others argue that capital requirements will do exactly the opposite and make banks pursue more risky strategies instead ${ }^{86}$. Unfortunately as is often the case in contemporary economics, theoretical analysis in this area delicately depends on the details of the modeling framework.

Moreover, one further assumption implicit in almost all theoretical models needs to be critically assessed: For all the arguments offered in the literature to be applicable, control over banks needs to be exercised by residual claimants with limited liability. Moreover, these owners have to be actively involved in bank management and have control over bank assets. However as Boot (2001) and Schmidt (2002) note, this is not a good description of the corporate governance of real world banks in most countries. In Germany, for example, a significant share of all banking institutions could be characterized as being manager controlled. The exercise of control rights by residual claimants in these institutions is weak at best. In some cases, notably in public banks like local savings banks and Landesbanks, a residual claimant in the usual sense does not even exist.

\footnotetext{
${ }^{84}$ See Santos (2000) for a survey of the literature.

${ }^{85}$ See Furlong/Keeley (1989) and (1990) for example.

${ }^{86}$ See for instance Kim/Santomero (1988).
} 
As well as co-operative and public banks, even the large private banks operated in the legal form of a stock corporation might fall into this category of manager controlled institutions. For example, the large private banks display ownership structures that are rather untypical for Germany in that they have widely dispersed ownership bases. Restrictions on voting rights have been commonplace in the past ${ }^{87}$ and a majority of voting rights in the annual meeting is exercised by the bank's own management (via proxy votes) and the management of other banks. In cases where some form of concentrated long-term participating interest was evident in the past, this was mostly held by other banks or by one of the large insurance companies. As a result, bank managers were in a particularly strong position and in the event that outside control was exercised, this was by their colleagues rather than by their shareholders. Bank managers, however, might have incentives quite different from those of limited liability residual claimants. ${ }^{88}$ Furthermore, for the risk-shifting problem to be virulent, it is important to have residual claimants whose ability to appropriate the gains from risky and successful strategies is not restricted in any way. Moreover, their liability needs to be limited in cases when the risky strategy turns out to be a disaster. In public banks as well as credit cooperatives there are no such owners, at least in the usual sense. ${ }^{89}$. For public banks, the absence of residual claimants is even more obvious. Here, for example, the fundamental ownership right of selling off the asset is legally not defined. Given the current state of the law of savings banks in most states, a municipality would neither be able to decide to sell the local savings bank to some outside investor ${ }^{90}$, nor could it force the managers of the savings bank to pay out dividends in excess of the limits defined by the respective state's Savings Banks Act. In the fiscal year 2000 only 2-3\% of the profits of all savings banks were distributed to their guarantors. ${ }^{91}$ Furthermore, because of the guarantee and maintenance obligation, in the past municipalities and states were fully liable with respect to any losses borne by the bank's creditors. There is considerable anecdotal evidence that because of the

\footnotetext{
${ }^{87}$ See Drukarczyk (1986) for a short description of the case of Deutsche Bank AG in 1975.

${ }^{88}$ Except for the case where their labour contracts display high powered incentive schemes. But there is no evidence that high powered contracts were in place in the past.

${ }^{89}$ For example, in a co-operative bank, except in the case where the bank is liquidated, no member is able to participate in increases in the banking firm's market value. When leaving the co-operative a member can only redeem her participation at par. Although many co-operatives pay out dividends, this does not seriously contradict our argument.

${ }^{90}$ The same holds true for the states and their Landesbanks. However, we have to note here, that as a consequence of interventions by the European Commission, most states are currently reforming their savings bank law with likely consequences for restrictions on dividend distributions and basic ownership rights.

${ }^{91}$ We thank the DSGV for providing this non-public information.
} 
negative effects on public budgets and the burden for the taxpayer, distress of savings banks or Landesbanks has a non-negligible impact on the re-election of mayors and state governments. ${ }^{92}$ Furthermore, as already mentioned above from our perspective it is an oversimplification to classify Landesbanks as "government owned" institutions as in La Porta et al. (2002). Closer examination of ownership structures of Landesbanks shows that on average the German states, the regional association of savings banks and other Landesbanks all hold around $30 \%$ of all ownership rights assigned. ${ }^{93}$

During the 1990s, there was a remarkable capital build-up of banks in industrialized countries. Jackson et al. (1999) show that in G-10 countries average bank capital ratios increased from $9.3 \%$ to $11.2 \%$ during the 1988 to 1996 period. Interestingly, this rise in capital ratios coincided with the agreement and implementation of the first Basle Accord. In Germany a similar pattern could be observed. Figure 4 below displays capital ratios (ratio of banks' capital to risk assets) for all German banks over the 1977 to 2001 period. Unfortunately data for the 1988 to 1993 period is missing but a likely path of the development of capital ratios is indicated by the dotted line. Besides regulatory requirements following the first Basle Accord, several other explanations for this capital build-up are offered in the literature, market discipline being one of them. ${ }^{94}$ Closer scrutiny of German data reveals interesting patterns, whose interpretations should take into account the specific features of the German banking system. Table 8 , therefore, contains information about bank capital ratios, growth in total assets, loans to non-banks and book equity broken down according to bank group.

\section{$<$ Figure 4 around here $>$}

As becomes apparent from table 8, during the 1990s all groups of banks seem to have improved their regulatory capital position. However, capital ratios in 1993 as well as in 2001 were higher for private banks than for public banks.

\section{$<$ Table 8 around here $>$}

\footnotetext{
${ }^{92}$ A recent example is the state of Berlin, where the state owned Bankgesellschaft Berlin nearly defaulted, which led to considerable cuts in public spending. As one consequence, the former state government was not re-elected.

${ }^{93}$ While these institutions themselves are state-owned, conflicts of interest are likely to play a role here. For example business relationships between savings banks and Landbanks are very close.

${ }^{94}$ Flannery/Rangan (2002) provide evidence in favor of the market discipline hypothesis for US banks.
} 
This might be interpreted as support for the widely accepted notion that state and municipal guarantees undermine market discipline and provide public banks with a competitive advantage. Despite these lower capital ratios, German Landesbanks' long-term credit rating, for example, has been one or two notches above that of their private banking competitors. ${ }^{95}$ According to Sironi (2001), investors' required return on subordinate debentures issued by European public banks is around 40 basis point lower than for otherwise comparable issues by private banks. ${ }^{96}$ Especially for the larger banks active in the large-volume-low-margin wholesale market this turns out to be a remarkable competitive advantage. Interestingly, the capital build-up indicated in figure 4 and table 8 is stronger for large banking institutions that refinance a larger part of their assets in the capital market. This is also true for the Landesbanks and co-operative central banks. By comparison the smaller retail banks refinanced more heavily by customer deposits have lower regulatory capital ratios.

\section{Licensing, supervision, and interventions}

Besides capital requirements, the second building block of bank regulation as laid down by the Banking Act is a supervisory process that accompanies a financial institution's life from the "cradle to the grave", that is, from licensing to (voluntary or forced) bank closure. Conducting banking business or providing financial services without being licensed by the FBSO is a punishable offence. Central aspects of the licensing procedure are concerned with the applicant's minimum initial capital, number, qualification and trustworthiness of managers and owners. Since 1976 licenses are no longer granted to sole proprietorships, but in general restrictions with respect to legal form do not exist. Interestingly, the group-specific deposit insurance schemes also have a role to play in the licensing process. The FBSO is required by law to consult them whenever a new license is granted. We will discuss the structure and role of deposit insurance in Germany further below. Whether the process of licensing by the FBSO, i.e. the indisputable degree of discretion left to the authority, has the effect of reducing the rate of entry into banking below the level already implied by the explicit regulations of the Banking Act themselves, is difficult to analyze. Similarly it is hard to analyze whether the licensing procedure is especially tough in Germany compared to other

\footnotetext{
${ }^{95}$ Moody's financial strength rating that disregards third party guarantees is C for most Landbanks, while it is B for four of the five private banks rated by this rating agency.

${ }^{96}$ It is important to note here that even private banks might benefit from an implicit guarantee by the government.
} 
countries. ${ }^{97}$ As indicated by figure 5, and given that during the 1995 to 2000 period there were roughly 3,000 credit institutions in Germany, entry into and exit out of the banking business was moderate at best. The number of new licenses granted by the FBSO was in the range of 20 to 30 per year. The category of returned licenses as displayed in the figure includes cases of failed banks as well as those that were closed for other reasons. It is a well-known fact in most countries that failure of banking institutions does not necessarily lead to market exit. In most cases failed institutions will instead be merged or taken over. This type of crisis resolution is also predominant in Germany's public banking as well as co-operative banking sector, where such transactions are orchestrated by the regional association of public or cooperative banks respectively. Especially among co-operative banks a significant share of all mergers that take place can be interpreted as rescue transactions. ${ }^{98}$ While this strategy of failure resolution leads to a reduction in the number of banks, it does not necessarily lead to market exit in terms of banking industry capacity (branches, employees, ATMs etc.).

\section{$<$ Figure 5 around here $>$}

Also displayed in figure 5 are the number of moratoria imposed by the FBSO.

Such strong interventions by supervisors, however, require that the supervisory agency be equipped with all the relevant information. No matter how tight the regulatory rules in restricting banks and no matter how serious the regulatory authority is in enforcing them, information continues to be asymmetrically distributed between supervisors and banks. Narrowing this informational gap, therefore, is of considerable importance for the effectiveness of bank supervision. The timeliness and accuracy of information largely determines whether supervisors are able to detect problems and take appropriate measures. For example, the overall costs of a banking crisis to be borne by society are significantly determined by the existence of a functioning early warning system. Furthermore, "gambling for resurrection" becomes a more serious problem the closer a bank is to default. If regulatory information is inaccurate and outdated, "zombie banks" are likely to stay in business and pursue excessively risky strategies thereby significantly increasing the cost of a banking crisis. ${ }^{99}$ On the other hand, maintaining a system of reports, audits and examinations is also a costly endeavor. In Germany the system of transferring information between banks and

\footnotetext{
${ }^{97}$ The Barth et al. (2001) data set on bank regulation has something to say about entry and licensing. However despite the impressive amount of information collected there, we would find it hard to make any judgement about effective entry restrictions on that basis.

${ }^{98}$ See also FSBO (2000).
} 
supervisory authorities (FBSO and the Bundesbank) is especially close and presumably relatively costly. Unfortunately no estimates of those costs are available. Supervisory authorities have far-reaching rights to obtain information and significant obligations to give information are imposed on credit institutions. It is remarkable, however, that neither the FBSO nor the Bundesbank have built up their own staff for audits and examinations and that they rely heavily on external auditors to perform these tasks. It is only recently, since on-site examinations of trading activity and internal market risk models have increased in importance, that these authorities have built up their own capacities. In the near future, the Basle II framework will necessitate further expansion of capacity for on-site examinations.

Credit institutions' obligations to provide information, either in the form of regular reports or upon the occurrence of specific events, are considerable. According to the Bundesbank (2000), in 1999, for example, there were 2,254,194 reports on large loans (pursuant to section 13 and 14 of the German Banking Act), 43,091 announcements of banks because of special events (section 24 of the German Banking Act), 213,172 reports in compliance with solvency and liquidity regulations (Principles I and II), 46,301 monthly reports on balance sheet items, 3,401 annual accounts and 2,690 auditors' reports on these annual accounts. Despite the large number of information items submitted to the supervisory agencies, external auditors' reports on the annual accounts remain the centerpiece of the information flow. External auditors have to comply with detailed auditing guidelines laid down by the FBSO and are subject to special duties according to the Banking Act (Section 29). While private banks are audited by independent third party auditors, the regional associations of savings banks as well as those of the co-operative banks have their own auditing staff. It is important to point out that for public banks as well as co-operative banks auditors commissioned by the FBSO are in most cases those of the regional associations of public and co-operative banks respectively. ${ }^{100}$

Among all information items available to the supervisory agencies, a distinguishing feature of auditor reports on annual accounts of banks is that they provide an assessment of risk, whereas most other reports do not. For example, the monthly reports submitted to the Bundesbank provide information on the volume of specific balance sheet items, but do not allow an assessment of price or credit risk to be made. By their very design instead, these reports seem to be much more useful as an empirical basis for monetary analysis. One

\footnotetext{
${ }^{99}$ A "zombie bank" is a bank that is already dead from an economic point of view, but still around in the marketplace.

${ }^{100}$ This is indeed a very special feature of audits of German banks and might raise doubts on auditors' independence.
} 
weakness of auditors' reports, however, is the low frequency at which they are made available by audits of the annual accounts.

Pursuant to section 44 of the Banking Act the FBSO has the right to order special audits without specific reason at every credit institution. There is some indication that the relevance of these special audits has been increasing throughout the 1990s. Supervisors thus try to intensify the flow of information from problem institutions. As figure 6 indicates the number of special audits according to section 44 has steadily increased from 1992 to 2000 with a peak in 1998. Whereas in 1992 around 6\% of all licensed credit institutions were subject to special audits in 1992 the share of audited institutions grew to around 15\% in 2000 (20\% in 1998). The largest part of these auditing activities can be attributed to co-operative banks that have faced serious difficulties in recent years.

\section{$<$ Figure 6 around here $>$}

\subsection{Deposit insurance - the private club model}

As mentioned in section 2 of this chapter, there might be a certain tendency to allow selfregulation of the banking industry in Germany. This can be illustrated by looking at the private club model of deposit insurance. In order to prevent the German government from implementing a publicly managed deposit insurance scheme, after the Herstatt crisis in 1974 the banking industry agreed to build up group-specific insurance systems. ${ }^{101}$ The scheme of the private banks was established and is operated by the representative body of private banks, the German Bank Association (Bundesverband deutscher Banken e.V.). Public savings banks and co-operative banks have their own group-specific schemes operated by their regional associations. ${ }^{102}$ Rather than only protecting non-bank deposits, these schemes are safeguarding the viability of the institution as a whole and are thus better described as support funds. Given that public banks are completely protected by guarantees and maintenance obligations by municipalities and states, a group-specific deposit insurance system can at best have subsidiary character and at first glance should not be expected ever to be claimed to pay out depositors. Although there is a clear priority of maintenance obligation and guarantee obligation (that is obligations of the municipality) over the deposit insurance scheme/support fund, these funds do indeed have a role to play. Most municipalities in Germany have large

\footnotetext{
${ }^{101}$ See Beck (2000) for a more detailed evaluation of the system of deposit insurance in Germany.

102 These regional funds, however, are tied together by so called "overflow agreements".
} 
budget deficits and in the event of the failure of a savings bank, when the maintenance (and guarantee) obligation is called for, they must refinance the necessary capital infusion in the capital market. This is where the deposit insurance/support fund of the regional association of savings banks steps in and often lends to the municipality at subsidized rates.

In what follows, our discussion will deal primarily with the insurance scheme for private banks, although some of the arguments apply as well to the co-operative and public banks' schemes. At first glance the most important peculiarity of the German deposit insurance system is its private organization. With respect to membership, several points deserve to be mentioned. Firstly the FBSO is by law required to consult the deposit insurance schemes before granting a banking license. This gives the deposit insurance scheme a quasi-official status in the licensing process. Interestingly, in the past there have been a few cases where the FBSO granted a license but the private banking association denied membership and insurance protection. Secondly, membership in the private banks' insurance scheme is voluntary but mandatory for members of the German Bank Association. Subsidiaries of foreign banks that are association members can, however, opt not to participate in the insurance scheme but only a few have chosen to do so. ${ }^{103}$ In principle the private banks' deposit insurance scheme could thus be used as an entry deterring mechanism, that is de novo banks could simply be denied membership and thus be put at a serious disadvantage in competition for depositors funds. In fact from the perspective of competition policy the deposit insurance scheme is seen as a cartel and thus is under the permanent scrutiny of the German Cartel Authority (Bundeskartellamt). ${ }^{104}$ Whether admission to the German Banking Association and its deposit insurance scheme was used by the incumbents as a means to keep competitors out of the market, is not easy to answer. Refusals of membership applications have not occurred very frequently in the past and among the 245 member institutions there are 80 subsidiaries of foreign banks. One such example, however, has been the case of Mody Bank AG in Hamburg. Although licensed by the FBSO, the German Bank Association repeatedly refused this small bank membership in its insurance scheme. After a newspaper report in 1995 about unsound business practices and mention of the fact that Mody's deposits were not insured, the bank experienced a "run by its depositors" and was subsequently closed by the FBSO. Denials of membership applications also occurred in the co-operative banking scheme.

\footnotetext{
${ }^{103}$ Voluntary scheme membership of foreign bank subsidiaries might thus be seen as an indication that being a club member provides banks with certain benefits.

${ }^{104}$ For example, every amendment of the deposit insurance scheme's charter will be examined and needs to be approved by the cartel authority.
} 
Protection of non-bank deposits is almost complete and amounts up to a limit of $30 \%$ of the capital of the credit institution in question. ${ }^{105}$ Given that there is no retention or co-insurance, coverage of the German system is by far the highest in the world. ${ }^{106}$ The system is financed solely by contributions of member institutions who pay a minimum premium of $0.03 \%$ of all customer liabilities (sight-, savings- and time deposits as well as savings certificates). In 1997 risk sensitive insurance premiums were introduced; Member banks are now rated annually according to a five notch rating system (A, B, and $\mathrm{C} 1$ to $\mathrm{C} 3$ ) and institutions with ratings other than A have to pay premia higher than $0.03 \% .{ }^{107}$ The annual report of the deposit insurance fund has to be submitted to the supervisory authorities but unfortunately it is not made public.

Apart from the involvement of the German Bank Association in the process of licensing, it is also significantly involved in the process of market exit. Again this involvement is accomplished through the deposit insurance scheme. In the event that a private bank and member of the insurance scheme fails, the insurance scheme pays out depositors of that institution and in turn becomes the largest and most important creditor of the failed bank. It thus gains control over the failed institution and has to make the decision either to liquidate or reorganize. In the case of Schröder, Münchmeyer \& Hengst, for example, the deposit insurance scheme had to put up roughly $€ 176$ million to pay out depositors and decided to split the bank into two parts, one of which was liquidated while the other was sold to a foreign bank. $^{108}$

According to the EU's Deposit Guarantee Directive of 1994, every EU member country is required to implement a statutory deposit insurance scheme on the basis of public law. It was implemented in Germany in 1998 and again used the established organizational structure of the relevant banking associations. Thus, even the statutory system is operated under the roof

\footnotetext{
${ }^{105}$ According to the German Banking Act, the minimum capital of a credit institution is $€ 5 \mathrm{mllion}$, so that every single non-bank deposit account is protected up to a limit of $€ 1,5$ million.

${ }^{106}$ However, it must be noted that reimbursement of depositors is non-statutory. There is no legally enforceable claim of depositors and troubled banks against the deposit insurance fund. The reason for this peculiarity is not to introduce uncertainty in order to foster market discipline by depositors, but rather to keep the fund from being subject to the regulations of insurance companies.

${ }^{107}$ As Beck (2000) reports, this premium can be "doubled or set at zero" depending on the financial condition of the insurance fund. Furthermore, there is a one time payment of 0.09\% for new members. See Beck (2002) for the details.

${ }^{108}$ See Beck (2001) for the details.
} 
of the respective banking association. Because of their far-reaching characteristic of safeguarding the viability of every single institution, public savings banks and co-operative banks are exempt from the requirement of establishing a statutory scheme. ${ }^{109}$ The new statutory scheme covering $90 \%$ of deposits up to a maximum amount of $€ 20.000$ takes the first hit, while the already existing schemes remain in place and supplement the statutory scheme. As a consequence of this implementation, the system of deposit insurance in Germany has not changed in any material way.

\subsection{Bank competition and SME financing}

Given our discussion above, the central issue of whether bank competition might be socially beneficial after all, and thus whether "more competition" can be regarded as a valid goal of bank (de)regulation, remains to be discussed. Standard economic thought predicts that more intense competition will lead to more efficient market outcomes in terms of price and quantities. This notion has implicitly underpinned our discussion so far and no specific attention was given to the many different market segments and customer groups served by (universal) banks. However, in the real world, all these markets are far from being perfect in terms of the absence of barriers to entry, the homogeneity of products and services and the distribution of information among market participants. ${ }^{110}$ Note here that the mere existence of banks and other financial intermediaries is generally explained by significant imperfections in financial markets. Asymmetries of information, the incompleteness of contracts and noncontractible liquidity risk, for example, are at the heart of the modern theory of the banking firm. As a consequence, this theory itself paves the way for arguments that cast doubt on conventional wisdom. In a static sense, therefore, perfectly competitive banking markets could yield capital allocations that are dominated by those that result from oligopoly market structures in terms of credit availability, growth and stability ${ }^{111}$. Furthermore, in a dynamic sense, and even if competition were unambiguously socially beneficial, deregulating financial services by simply lifting formerly imposed restrictions need not necessarily lead these markets to converge towards the competitive benchmark. A more recent strand of the economic literature at the interface between finance and IO therefore analyzes bank competition in imperfect markets for financial services. In the remainder of this section we

\footnotetext{
${ }^{109}$ Two new systems have been established: one for private banks and one for special purpose public banks that are not members of the support fund of the savings banks.

${ }^{110}$ To put it differently, what market outcomes should be expected in financial markets when the assumptions underlying the fundamental welfare theorems are not met? See also Laffont (1998) for this problem.

${ }^{111}$ See Perrotto/Cetorelli (2000) and Caminal/Matutes (2000) for examples.
} 
will focus on SMEs (small and medium-sized enterprises) and their external financing needs and will thus consider only one of the many markets and customer groups to be served by banks. From our perspective, there are several reasons why providing loans to SMEs is especially well suited to analyzing the effects of bank competition. Informational problems that are of great theoretical interest play a significant role in SME financing and might in turn have a considerable influence on equilibrium market structures. ${ }^{112}$ Furthermore, borrower size might be somehow related to bargaining power in loan negotiations. ${ }^{113}$ Even small differences in bank competitiveness across markets might therefore have a pronounced effect on SME financing. Besides, SMEs represent an important part of the German economy in terms of investment, value added, employment, and innovative activity. ${ }^{114}$

In a widely cited paper Petersen/Rajan (1995) argue that bank market power positively affects bank credit availability especially for young and risky borrowers. Given that informational and related incentive problems are a major obstacle to lending to these firms, banks with market power could weaken such problems by lending at concessionary rates when problems threaten to be severe. It is well-known that in a perfectly competitive market problems of this type could lead to credit rationing. In a less than perfectly competitive credit market, however, firms with lower credit quality might be able to obtain funding. The argument is based on an inter-temporal smoothing effect. In later periods and by virtue of their market power, banks are able to extract a larger part of the project surplus from the good customers who survive. In the first period, therefore, banks grant loans even to the more risky loan applicants, because lender market power is like an implicit equity stake in the firm.

The empirical evidence in Petersen/Rajan (1995) indicates that small US firms located in more concentrated banking markets (i) show a stronger reliance on debt financing by financial institutions, (ii) take early payment discounts more frequently, and (iii) pay lower loan rates when young, and higher loan rates when old compared to similar firms based in more

\footnotetext{
${ }^{112}$ Guided by the modern theory of the banking firm one might argue that this is exactly why bank loans play such an important role empiricallyin SME financing. On the other hand, informational problems might well feed back into bank market structures because inter-temporal aspects of business relationships to SMEs might constitute serious barriers to entry.

${ }^{113}$ Most empirical studies that regress corporate loan rates on a set of explanatory variables reveal that borrower size (sales, total assets or loan size) is a statistically and economically significant determinant of loan rate margins even if borrower default risk is accounted for. See the evidence in Elsas/Krahnen (1998) or Hanser (2001) for Germany and Berger/Udell (1995) or Berlin/Mester (1999) for the US. The fixed cost of granting loans could be seen as an alternative explanation for this phenomenon.

${ }^{114}$ According to DSGV the 3.3 million SMEs in Germany (sales below $€ 5$ million) account for $50 \%$ of gross investment, $60 \%$ of total assets and even $70 \%$ of employment.
} 
competitive markets. More recently Zarutskie (2003) finds that small US firms use more bank debt and less debt provided by firm insiders in more concentrated markets, confirming evidence in Petersen/Rajan (1995). A similar but more differentiated picture is drawn by Cetorelli and Gambera's (2001) study. These authors use cross-country, cross-industry data to assess the effects of banking market concentration on growth of non-financial industries. The cross-country dimension of their data allows them to measure the impact of more or less concentrated banking market structures on the growth of the average industry. The within country cross-industry dimension raises the more intriguing question of whether this effect is equal across all industries considered. ${ }^{115}$ From Cetorelli/Gambera (2001) two results emerge. Firstly, the standard argument that market power by banks depresses the growth of loan customers cannot be rejected. This is in line with conventional wisdom. Secondly, there are some industries that might benefit from a less competitive banking environment as this improves the availability of bank loans as a source of external finance. It must, however, be noted that the empirical work in Cetorelli/Gambera (2001) or Petersen/Rajan (1995) is not fully able to discriminate among different possible hypotheses that link bank market power and credit availability.

Are there indications that similar results also apply in Germany? Do small and medium-sized enterprises more readily find access to bank credit in more concentrated banking markets? Given the importance of SMEs, banks and bank loan financing in Germany, this seems to be a question of considerable interest.

To give a first basic impression, table 9 displays summary statistics from a widely used commercial database provided by Verband Creditreform, the largest credit bureau for corporate customers in Germany. ${ }^{116}$ From this data bank we select all firms that belong to manufacturing, construction and mining with balance sheets that are available at least once during the 1994 to 1997 period and annual sales below EURO 25 million. ${ }^{117}$ We split the group of firms into two sub-samples according to whether the firms' headquarters are located in the eastern or western part of Germany. As shown in table 2 above, local banking markets in eastern Germany are much more concentrated than their west German counterparts. Thus in order not to bias results, a sample split is warranted. In a second step these sub-samples are

\footnotetext{
${ }^{115}$ Cetorelli/Gambera (2001) are especially interested in the cross-industry differences in external financing needs of young enterprises. The dependent variable in their regressions is the average (compounded) rate of growth of real value added for each industrial sector in each country between 1980 and 1990.

${ }^{116}$ We thank Verband der Vereine Creditreform e.V. for providing the data.

${ }^{117}$ For computing the following variables, we average over years to construct a cross-section data set.
} 
split according to our measure of local banking market concentration. For the west German sub-sample a threshold level of 0.17 for the local Herfindahl was used, while for the east German sub-samples the respective value was 0.28 . For every pair of observations, the average ratio of bank loans to total assets is higher for firms located in those areas where banking is more concentrated. Similarly, the share of firms that use bank loans as a source of funding is significantly higher in these markets. Although this evidence is more anecdotal ${ }^{118}$, it is nevertheless remarkable that it is in such stark contrast to conventional wisdom which suggests that bank concentration will lead to higher loan rates and lower loan volume.

\section{$<$ Table 9 around here $>$}

As already mentioned above $\mathrm{e}^{119}$, the relationship between concentration and bank loans as a source of SME financing displayed in table 9 could as well be driven by reverse causality. According to this, banking markets are more concentrated simply because firms located in these markets are more risky and less transparent. Given that the cost of granting loans to these firms is higher, only few banks have entered because only few of them could operate profitably. Furthermore, these more risky and opaque firms have few alternatives to bank loans, when looking for sources of outside finance because banks specialize in lending to risky and opaque borrowers. The relationship between concentration and bank loans displayed in table 9 might therefore arise as a natural consequence of the uniqueness of bank loan financing. This latter point is a centerpiece of the modern theory of the banking firm. ${ }^{120}$ However, while the average quality of borrowers in a market is a determinant of bank market structure, banks should be expected to devote considerable resources to distinguishing good borrowers from bad ones. If this holds true, differences in average borrower quality between high and low-concentration markets should not be sufficient to explain the pattern in table 9 . Instead, for the reverse causality story to have any meaning, the quality of firm used to build the sub-samples in table 9 should be different, with the frequency of "lemons" being higher in more concentrated markets. Matching sub-samples of firms of comparable quality could, therefore, be one way to check whether the theory in Petersen/Rajan (1995) explains at least part of the patterns in table 9. Unfortunately, with only balance sheet data at hand, the risk and opaqueness of firms is not easy to assess. As a crude proxy, we use industry classification and

\footnotetext{
${ }^{118}$ In particular, we have not controlled for any form of sample selectivity!

${ }^{119}$ See footnote 51 further above!

120 See Diamond (1984) and (1991).
} 
firm size (measured by total assets) to control for firm opaqueness. Overall the results displayed in table 9 seem to hold even after controlling for firm size and industry. As an example table 10 shows averages of the ratio of bank loans to total assets for all sample firms belonging to the construction sector ${ }^{121}$ where the sub-sample is split according to firm size (measured by total assets).

\section{$<$ Table 10 around here>}

The relationship between bank loan financing by SMEs in the construction sector and local banking market concentration seems to hold across all size classes. Similar results are obtained for manufacturing firms. ${ }^{122}$

Although providing only anecdotal evidence, the pattern that shows up in tables 9 and 10 is very much in line with the predictions derived from Petersen and Rajan's theory. Furthermore it confirms empirical evidence from the US. ${ }^{123}$ Interestingly, the results seem in general to be stronger in eastern Germany where firms are significantly younger and riskier than in the western part. In Petersen/Rajan (1994) and (1995) the share of early payment discounts taken by the firm is also used as a measure of credit availability and it is found that this share is higher for firms located in more concentrated banking markets. Using a similar variable and survey data for small and medium-sized firms in Germany, Fischer (2000) finds a positive relationship between local banking concentration and the frequency of early payment by these German firms. According to Petersen/Rajan (1995), for example, banks with market power are better able to provide liquidity because of their ability to lend at concessionary rates in troubled times and extract larger parts of the project surplus during successful periods.

There is, however, a closely connected notion and complementary mechanism that might drive these results. It points to the relationship between bank market power and the incentives to invest in borrower specific information. ${ }^{124}$ If close informational ties between banks and borrowers are value enhancing, then market power enables banks to appropriate a larger share of that incremental value via higher loan rates, which in turn makes information acquisition

\footnotetext{
${ }^{121}$ According to German industry classification WZ93.

${ }^{122}$ Since manufacturing firms are more heterogeneous, we also switched to finer industry classification. Unfortunately the number of firms in each size industry cell rapidly becomes insufficient to obtain meaningful statistical inferences.

${ }^{123}$ See Petersen/Rajan (1995) and Zarutskie (2003).

${ }^{124}$ See for example Caminal/Matutes (2002a) and (2002b).
} 
and relationship lending more profitable from the bank's perspective. Fischer (2000) puts this hypothesis to the test and finds that in Germany information acquisition by banks is more intense in more concentrated markets. In a loan application situation firms located in these areas have to disclose more private information to their banks. The study uses data on information items transmitted to the lending bank in a loan application situation. Besides merely measuring the number of information items, it also distinguishes between what could be termed hard and soft information. All regressions control for firm variables, loan variables, relationship variables and other variables related to the local market. Bank market concentration has a positive effect on the amount of information disclosed to the bank and further makes transmission of soft information significantly more likely. ${ }^{125}$

The reusability feature of information in turn allows these better informed banks to provide liquidity at short notice without incurring any additional costly transfer of information. Firms that have experienced a liquidity shock therefore provide an opportunity to conduct a natural experiment on the concentration-information relationship. If it were true that banks in more concentrated markets systematically acquire more information about their customers and if this information is somehow reusable in later periods, these firms should be expected to submit less additional information to their lenders whenever they are in need of liquidity at short notice. The empirical evidence in Fischer (2000) strongly supports this notion. Overall there seem to be benefits and costs of more intense competition among banks. While the benefits are well understood, the costs have only recently become the subject of economic discussion and have begun to be analyzed. The incentives to acquire information about borrowers, thus incurring higher costs within the credit process as a result, might be one such source for the likely social benefits of market power of banks. The implications of these findings on information acquisition and monitoring intensity, however, go well beyond the analysis of the effects of bank competition for small firm finance. Of equal importance are the consequences related to bank soundness and loan portfolio risk. ${ }^{126}$ Moreover, to date we do not have a very good understanding of how monitoring, diversification and other aspects of bank credit policy contribute to a loan portfolio's risk-return profile. ${ }^{127}$

\footnotetext{
${ }^{125}$ For details see Fischer (2000).

${ }^{126}$ Thus, for example, in an environment with aggregate risk Caminal/Matutes (2002) analyze the effect of bank competition on monitoring incentives and the probability of bank failure.

${ }^{127}$ See Winton (1999) for a discussion and a model of the interaction between loan monitoring and diversification.
} 


\section{Conclusion}

\subsection{How should we interpret the past and present?}

When German bank regulation was first established in the 1930s and re-established after World War II, it faced a banking industry characterized by inherited structural peculiarities in both instances. The German banking system was and still is characterized by the existence of three strong groups or networks of suppliers of financial services: A host of small retail banks was historically tied together within the multi-layer organizations of the co-operative and public banking sector. The group of private banks was dominated by a few large universal banks. The group character is least strong and least obvious for private banks, but as our discussion of the deposit insurance scheme has suggested, it also shows important features of peer control and self-regulation. In general there has been a tendency to allow these groups to build their own systems, to monitor each other, and even to organize the bail-out of a failed institution within the group, rather than with the assistance of regulatory authorities. In some sense, regulators have made use of these banking sub-systems and even delegated quasiregulatory responsibilities (e.g. auditing, deposit insurance, bail-out policies) to them.

It is not only that the actual implementation of regulatory activity has somehow adjusted to this inherited structure of the banking market. It is also that competition in German banking might still be best described as competition primarily among groups of banks. As a further consequence of this peculiarity, the larger part of all structural adjustments in the past has taken place within these groups rather than by shifting the boundaries dynamically between them. This is not only true for structural adjustments related to the banking business itself (with respect to products, markets, technology etc.), but it also holds for challenges posed by regulation. Despite the fact that the banking industry has faced serious challenges during the decades since World War II, market shares and the relative importance of the co-operative, public and private banking sectors have thus been remarkably stable over time. Germany`s banking associations have become enormously important in coordinating the industry and industry's interactions with regulators. Furthermore, they provide vehicles that perform certain tasks characterized by considerable economies of scale. For example, they currently play an enormously important role in building internal rating systems that fit into the Basle II framework to assess a borrower's probability of default. ${ }^{128}$

\footnotetext{
${ }^{128}$ See Schenk (2002) for further details.
} 
Since World War II monetary policy by the Bundesbank, i.e. its overall strategy and specific form of conduct have also had a role to play. On several occasions, the monetary authority undermined financial innovation, involving the introduction of short-term securitized money market instruments and derivative instruments in particular, thereby preventing bank charter values and preserving the inherited structure. ${ }^{129}$ What is even more important is that this structural stability has also conserved manager-oriented as well as inter-bank-oriented governance structures. High powered, owner-oriented incentive schemes, in turn, did not have much of a role to play in the past. The group character and the specific governance structures might have contributed more to the stability and soundness of German banking, than any market power German banks were suspected to exercise.

In the introduction to this chapter it was noted that many observers considered German banking to be stable but not very competitive and further suspected that both these characteristics might be somehow interrelated. With respect to the competitive issue, caution should be exercised before deriving strong conclusions from anecdotal ${ }^{130}$ as well as econometric evidence. While there is a strong public perception about the "power of banks" in Germany, empirical IO could hardly be interpreted as offering strong supportive evidence. Even if the methodological problems of this research are taken into account, German banking, at least in recent years, seems to have been be fairly competitive. International comparisons also indicate that German banking is competitive relative to most other European markets. Whether this was also the case in earlier times, remains somewhat unclear. Further research applying more sophisticated empirical methods is urgently required. However, a prerequisite for constructing good models might be a better understanding of the implications of the specific structural features of the German banking system. What does it mean to have strong public banking sector acting like a large financial conglomerate, displaying features of political interference as well as self-regulation? The same question can be raised with respect to the stability issue. What are the implications of this banking business structure for future developments?

\subsection{What the future might bring}

\footnotetext{
${ }^{129}$ This point is highlighted by Franke (2000).

${ }^{130}$ Besides a widely recognized but fairly general public discussion about the "power of banks", this issue has also kept occupied parliamentary committees as well as political parties in Germany for decades.
} 
What does all this imply for the future of German and European banking? What are the implications of this banking business structure for future developments? One implication might be that the most dramatic changes in German banking are to be expected, whenever the boundaries between the banking groups shift. One such occasion could be the implosion of a banking group, when widespread defaults could not be handled within the group system anymore and some outside help would be required. Although it is classified as an extreme scenario, taking a look at recent banking crises elsewhere, suggests that events of this type should not be ruled out entirely in the future. In the introduction to this chapter we already made brief reference to the current notion of a general banking crisis in Germany. ${ }^{131}$

While some would argue that this crisis is "systemic" and thus a serious threat to the overall economy, others do not expect German banks to be severely hit by a solvency or liquidity crisis in the near future. ${ }^{132}$ Overall, however, there is little doubt that the German banking system is in dire straits, a fact that may be attributed to two main reasons, economic and structural. ${ }^{133}$ On the economic side, the German economy is performing poorly, even by comparison to other continental European countries. Stock markets have plummeted and bank profits from trading, underwriting and M\&A advisory services, for example, have deteriorated. Furthermore, profitability of traditional loan-related business has been seriously affected by non-performing loans as well. As a consequence of the poor economic conditions in Germany, borrower default rates are at record levels. According to Creditreform, 37,700 firms defaulted in 2002 (26,600 in western Germany and 11,100 in the east), with a rate of growth of $16.4 \%$ compared to the previous year and $41.6 \%$ as compared to $1999 .{ }^{134}$ Badloan provisions by German banks have recently increased dramatically.

\footnotetext{
${ }^{131}$ Even the IMF has recently scrutinized the German banking system within its Financial Stability Assessment Program (FSAP).

${ }^{132}$ As an example of this perspective, see Sam Theodore (2003) of Moody's, who in March 2003 did not expect the rating of major German banks to slide below the "mid to low A/Prime-1 range".

${ }^{133}$ We again refer to Hackethal's (2003) contribution to this volume for empirical evidence on the low profitability of German banks in recent years.

${ }^{134}$ Banks in turn have become much more cautious in their loan granting policies. Survey data from different sources seem to indicate that especially small firms had difficulty obtaining credit in 2002 . For the first time in Germany therefore, there is strong indication that a "credit crunch" might accentuate the economic downturn and exert an important pro-cyclical effect.
} 
On the structural side, the low earning power of German banks seems to be systematically affected by the high level of market fragmentation. ${ }^{135}$ As already mentioned, even the largest German banks have domestic market shares that are considerably smaller than their counterparts in other European countries. However, the fragmented structure of the German market is most directly related to the role of the public banking sector. Municipalities and states own banks that are allowed to offer a full range of relevant banking services and furthermore provide them with guarantees that lower their cost of capital. For many observers, this is a major obstacle to private banks' profitability. It is indeed questionable whether public and co-operative banks, classified as non-profit making entities, have in the past put enough emphasis on pricing their products in order to achieve returns that are appropriate for the risks that they take. ${ }^{136}$ On the other hand, in a world of capital requirements, these institutions have always been forced to fully retain earnings in order to strengthen their capital base and be able to grow. ${ }^{137}$

When this chapter was written in spring of 2003, the German banking crisis was still in a somewhat unresolved state. While no serious bank default had occurred to date, the weak economic outlook for Germany and the rest of Europe has made us cautious with respect to making any premature assessment of the German experience.

With respect to changing industry structures, a less extreme but much more likely scenario than a severe crisis, can be seen in the widespread willingness to privatize public banks or demutualize co-operative banks in Germany. Privatization of public banks has not yet taken place but has been the subject of intense discussions for quite some time now. What is therefore required is a serious evaluation of the advantages and disadvantages of having and maintaining a public banking sector in a developed country like Germany. An evaluation of this kind would also require public banks' performance in stimulating and stabilizing regional development to be evaluated. This issue is particularly important with respect to SMEs and low income households. Given that German SMEs are often seen as the backbone of economic activity, this discussion will be of vital importance for the future.

\footnotetext{
${ }^{135}$ See section 1.4 of this chapter further above.

136 This might have had the effect of keeping margins down.

${ }^{137}$ In section 1.3 of this chapter we noted that general mandatory capital requirements for banks were introduced as early as 1934 in Germany.
} 
In the US as well as in the UK there have been serious discussions in the recent past about whether banks need be required to target at least part of their retail business policies towards their own community and the SMEs and households located there. The Community Reinvestment Act of 1977, which was revised in 1995, was intended to encourage US banks to meet the credit needs of the low and moderate income neighborhoods in their communities. In the UK the Cruickshank report proposed to take measure that improve the access to basic banking services by low income individuals and households. ${ }^{138}$

Public savings banks in Germany have convincingly argued that such policy measures were unnecessary in the past because savings banks, pursuing a public mission and acting in their home community's best interest, provide a stable source of financial services to all groups of customers. Their business strategies are especially tailored to cater for private customers and SMEs. Basic descriptive statistics are sufficient to show that public banks are especially active in financing young and small enterprises as well as households of all income levels. From an economic point of view, however, the relevant question is whether this is merely a crowding-out effect due to the competitive advantages provided by government guarantees.

As is well known, in 1998 German private banks initiated proceedings against the system of state and municipal guarantees for public banks at the European Commission. Although much more fundamental in its significance, the actual complaint was triggered by a transfer of a state-owned building and real estate company from the state of North-Rhine-Westphalia to WestLB (Westdeutsche Landesbank), thereby strengthening WestLB's capital base. In 2001 the Commission required the German government to adopt "appropriate measures" to make the whole system of guarantees compatible with state aid rules in the EU treaty. In February 2002 the European Commission, the German Federal Government and State Governments as well as the Association of Savings Banks and Landesbanks reached an agreement to restructure the guarantee mechanisms for public banks in Germany. According to this agreement the maintenance obligation will be replaced and the guarantee obligation will be abolished. ${ }^{139}$ This will make financing in international capital markets significantly more costly for Landesbanks. ${ }^{140}$ As a consequence of this agreement, there is little doubt that

\footnotetext{
${ }^{138}$ See Cruickshank (2000), Executive Summary, p. xxiv

${ }^{139}$ Existing liabilities (as of July 18, 2001) will fully be covered by the guarantee obligation (Gewährträgerhaftung) until their final date of maturity (grandfathering). The maintenence obligation has to be replaced by a "normal commercial owner relationship governed by market economy principles". The latter makes necessary a reform of the Law of Savings Banks in all German states.

${ }^{140}$ WestLB was the first Landbank to restructure in response to these new challenges. In September 2002 WestLB split up into two independent banks that will be associated in a parent-subsidiary relationship. WestLB
} 
Landesbanks have come under heavy pressure to cut operating costs and restructure their business portfolio. While many Landesbanks were active in wholesale banking in the past, without state guarantees this does not seem to be profitable anymore. Many observers thus recommend that they tie in with the savings banks in their region to integrate retail business activities. ${ }^{141}$ However, it seem highly doubtful whether savings banks will be willing to share even a small portion of retail business activities with them.

It is not at all clear what all this means for the future of public banking in Germany. Rather than an immediate shift in the ownership structures of public-sector banks, privatization of public banks will occur gradually over longer periods of time. In general, such conversion of legal forms may be seen as a prerequisite for further and intensified M\&A activity, which might be an important option for the future restructuring of the industry. Especially in the retail segment, we expect considerable pressures towards industry consolidation and reorganization to arise in the future.

will continue to be an internationally active universal bank, while NRW will be a development bank with a "public mission"

${ }^{141}$ Especially the rating agencies recommend such refocus. See Skelly (2002). 
References

Allen, F./Gale, D. (2000) Comparative financial systems, MIT Press, Cambridge, Mass.

Amel, D.F./Starr-McCluer, M. (2001): Market definition in banking: Recent evidence, Working Paper, Board of Governors of the Federal Reserve System

Angelini, P./Cetorelli, N. (1999): Bank competition and regulatory reform: The case of the Italian banking industry, Working Paper, Federal Reserve Bank of Chicago

Barth, J./Caprio, G./Levine, R. (2001) The regulation and supervision of banks around the world - A new database, Working Paper, Worldbank

Barth, J./Caprio, G./Levine, R. (2002) Bank regulation and supervision - What works best?, Working Paper, Worldbank

Beck, T. (2001): Deposit insurance as private club. Is Germany a model?, Working Paper World Bank, Washington D.C.

Berger, A.N./Hannan, T.H. (1989): The price concentration relationship in banking, Review of Economics and Statistics, S. 291-299

Berger, A.N./Kashyap, A.K./Scalise, J.M. (1995): The transformation of the US banking industry: What a long strange trip it's been, Brookings Papers on Economic Activity, pp.55218.

Berger, A.N./Udell, G.F. (1995): Relationship lending and lines of credit in small firm finance, Journal of Business, Vol. 68, No. 3, pp.351-381

Berlin, M./Mester, L.J. (1998): Deposits and relationship lending, Review of Financial Studies

Bhattacharya, S./Boot, A.W.A./Thakor, A.V. (1998): The economics of bank regulation, Journal of Money, Credit, and Banking 30, pp.745-770.

Bikker, J.A./Groeneveld, J.M. (2000): Competition and concentration in the EU banking industry, Kredit und Kapital, Heft 1/2000, pp. 62-98

Boot, A.W.A: (2001): Regulation and banks' incentives to control risk, Sveriges Riksbank Economic Review, 2/2001, pp. 14-24.

Boot, A.W.A./Thakor, A.V. (1997): Banking scope and financial innovation, Review of Financial Studies 10, pp. 1099-1131.

Borenstein, S. (1989): Hubs and high fares: dominance and market power in the US airline industry, RAND Journal of Economics, Vol. 20, No. 3, pp. 344-365

Bresnahan, T.F. (1989): Empirical studies of industries with market power, in Schmalensee, R. and Willig, R.D., Handbook ogf Industrial Organization, pp. 1011-1055

Bundesbank (1997)The longer-term trend in savings deposits and its implications for monetary targeting, Monthly Report, May 1997 
Bundesbank (2000) The Bundesbank's involvement in banking supervision, Monthly Report September 2000

Bundesbank (2001) Bank balance sheets, bank competition, and monetary transmission, Monthly Report, September 2001

Caminal, R./Matutes, C. (2000a) Can competition in the credit market be excessive? , Working Paper No.1725 Center for Economic Policy Research

Caminal, R./Matutes, C. (2000b) Bank solvency, market structure, and monitoring incentives, International Journal of Industrial Organization

Cerasi, V./Chizzolini, B./Ivaldi, M. (1998) Sunk costs and competitiveness of European banks after deregulation, Working Paper London School of Economics, Financial Markets Group

Cetorelli, N./Gambera, M. (2001) Bank market structure, financial dependence and growth: International evidence from industry data, Journal of Finance, Vol. LVI, No. 2, pp. 617-648

Courvoisier, S./Gropp, R. (2002) :Bank concentration and retail interest rates, Journal of Banking and Finance 26, pp. 2155-2189

Cruickshank, D. (2000): Competition in UK banking - A report to the Chancellor of the Exchequer, Norwich.

Cukierman, A. (1992): Central bank strategy, credibility, and independence, MIT Press, Cambridge, Mass.

Danthine, J-P./Giavazzi, F./Vives, X./von Thadden, E-L. (1999): The future of European banking, CEPR, London.

De Bandt, O./Davies, A.E.P. (1999): A cross-country comparison of market structures in European banking, Working Paper, European Central Bank, Frankfurt

Degryse, H./Ongena, S. (2001): Distance, lending relationships, and competition, Working Paper CentER, Tilburg

Demsetz, R.S./Saidenberg, M.R./Strahan, P.E. (1996):Banks with something to lose: The disciplinary role of franchise value, Economic Policy Review Federal Reserve Bank of New York, October 1996, pp. 1-14.

Dewatripont, M.Tirol, J. (1994): The prudential regulation of banks, MIT Press, Cambridge, Mass.

Diamond, D.W. (1984): Financial intermediation and delegated monitoring, Review of Economic Studies 51, pp. 393-414.

Diamond, D.W (1991): Monitoring and reputation: The choice between bank loans and directly placed debt, Journal of Political Economy 99, pp. 689-721.

Domowitz, I./Hubbard, R.G./Petersen, B.C. (1986): Business cycles and the relationship between concentration and price-cost margins, RAND Journal of Economics, Vol. 17, No. 1, S. $1-17$ 
Elsas, R./Krahnen, J.P. (1998): Is relationship lending special? Evidence from credit file data in Germany, Journal of Banking and Finance 22, S. 1283-1316

Federal Banking Supervisory Office (2001) Annual Report 2000, Bonn

Fischer, K-H. (2000): Acquisition of information in loan markets and bank market power An empirical investigation, Working Paper, Goethe University, Frankfurt

Fischer, K-H. (2001): Banken und unvollkommener Wettbewerb - Empirische Beiträge zu einer Industrieökonomik der Finanzmärkte, Dissertation, Goethe University Frankfurt

Fischer, K-H./Hempell, H.S. (2003): Oligopoly and conduct in German banking, Forthcoming, Working Paper, Goethe University Frankfurt

Flannery, M.J./Rangan, K. (2002) Market forces at work: Evidence from the capital buildup in the 1990s, Working Paper, University of Florida

Franke, G. (2000): Deutsche Finanzmarktregulierung nach dem Zweiten Weltkrieg zwischen Risikoschutz und Wettbewerbssicherung, Working Paper, Center for Econometrics and Finance, University of Konstanz

Franzke, S./Grohs, S./Laux, Ch. (2003) Initial public offerings and venture capital in Germany, forthcoming, The German Financial System, edited by Jan Pieter Krahnen and Reinhard H. Schmidt, Oxford University Press.

Freixas, X./Rochet, J-C. (1997): Microeconomics of banking, MIT Press, Camridge, Mass.

Furlong, F.T./Keeley, M.C. (1989) Capital regulation and bank risk taking: A note, Journal of Banking and Finance 13, pp. 883-891

Genesove, D./Mullin, W.P. (1998): Testing static oligopoly models: Conduct and cost in the sugar industry, 1890-1914, RAND Journal of Economics, Vol. 29, No. 2, pp. 355-377

Goodhart, C.A.E./Schoenmaker, D. (1993): Institutional seperation between supervisory and monetary agencies, in: F. Bruni (ed.) Prudential Regulation, Supervision and Monetary Policy, Milano, pp. 353-439 (reprinted in Goodhart, C.A.E. (1995): The Central Bank and the Financial System, MacMillan Press, Basingstoke).

Gual, J./Neven, D. (1993): Deregulation in the European banking industry, 1980-1990, European Economy, Vol 3, pp. 151-182.

Hackethal, A (2003): Banks and banking structure, forthcoming, The German Financial System, edited by Jan Pieter Krahnen and Reinhard H. Schmidt, Oxford University Press

Hanser, F. (2001): Die Struktur von Kreditbeziehungen, Gabler, Wiesbaden.

Hellwig, M. (2000): Banken zwischen Politik und Markt: Worin besteht die Volkswirtschaftliche Verantwortung der Banken? Perspektiven der Wirtschaftspolitik 1(3), pp. 337-356

Hempell, H.S. (2002): Testing for competition among German banks, Discussion Paper No. 04/02, Deutsche Bundesbank, Frankfurt. 
Herring, R.J./Litan, R.E. (1995): Financial regulation in the global economy, The Brookings Institution, Washington D.C.

Jackson, P. et al. (1999) Capital requirements and bank behaviour - The impact of the Basle accord, Working Paper, Basle Committee

Jayaratne, J./Strahan, P.E. (1996): The finance-growth nexus: Evidence from bank branch deregulation, Quarterly Journal of Economics , pp. 639-670.

Kaen, F.R./Sherman, H.C./Teheranian, H. (1997): The effects of Bundesbank discount and lombard rate changes on German bank stocks, Journal of Multinational Financial Management 7, pp. 1-25.

Keeley, M.C./Furlong, F.T. (1990) A re-examination of the mean-variance analysis of bank capital regulation, Journal of Banking and Finance 14, pp. 69-84

Kim, D./Santomero, A.M. (1988) Risk in banking an capital regulation, Journal of Finance 43, pp. 1219-1233

Kroszner, R. (2001) The motivations behind banking reform: Why do lawmakers pursue deregulation? Regulation, Summer, Vol 24, no. 2, pp. 36-41

Kroszner, R.S./Strahan, P.E. (1999): What drives deregulation? Economics and politics of the relaxation of bank branching restrictions, Quarterly Journal of Economics, pp. 1437-1467

Krümmel, H-J. (1980): German universal banking scrutinized, Journal of Banking and Finance

Krümmel, H.-J. (1983): Bankenaufsichtsziele und Eigenkapitalbegriff, Fritz Knapp, Frankfurt a.M.

Laffont, J.-J. (1998): Competition, information and development, Annual World Bank Conference on Development Economics, ed. b. B. Pleskovic und J.E. Stiglitz, The World Bank, Washington D.C., pp. 237-257

Lang, G. (1997): Wettbewerbsverhalten deutscher Banken- Eine Panelanalyse auf Basis der Ross-Panzar Statistik, Jahrbuch für Wirtschaftswissenschaften - Review of Economics 48, pp. 21-38.

La Porta, R./Lopez-de-Silanes, F./Shleifer, A. (2002) Government ownership of banks, Journal of Finance 57, pp. 265-301.

Levine, R. (1997): Financial development and economic growth: Views and agenda, Journal of Economic Literature 35, pp. 688-726.

Lewellyn, D.T. (2000): Alternative approaches to regulation and corporate governance in financial terms, Financial Stability and Central Banks: A global perspective, Brealey, R.A., Clark, A., Goodhart, C., Healey, J., Hoggarth, G., Lewellyn, D.T., Shu, C., Sinclair, P. and Soussa, F. (eds), Routledge, London and New York , 2001, 
Molyneux, P./Lloyd-Williams, D.M./Thornton, J. (1994): Competitive conditions in European banking, Journal of Banking and Finance 18, pp. 445-459

Neuberger, J.A./Zimmerman, G.C. (1990): Bank pricing of retail deposit accounts and "the California rate mystery“, Economic Review, Federal Reserve Bank of San Francisco, Spring 1990, S. 3-17

Neven, D./Röller, L-H. (1999): An aggregate structural model of competition in the European banking industry, International Journal of Industrial Organization 17, pp. 1059-1074

Neven, D./Von Ungern-Sternberg (1998): The competitive impact of the UBS-SBC merger, Working Paper University of Lausanne

OECD (1992): Banks under stress, OECD, Paris

Perotto, M./Cetorelli, N. (2000) Oligopoly Banking and Capital Accumulation, Working Paper, Federal Reserve Bank of Chicago

Petersen, M.A./Rajan, R.G. (1994): The benefits of firm-creditor relationships: Evidence from small business data, Journal of Finance 49, pp. 3-37.

Petersen, M.A./Rajan, R.G. (1995): The effect of credit market competition on lending relationships, Quarterly Journal of Economics, Vol. 110, S. 407-443

Rajan, R.G. (1996): The entry of commercial banks into the securities business: A selective survey of theories and evidence, Universal Banking, ed. by A. Saunders and I. Walter, Irwin, Chicago.

Ribon, S./Yosha, O. (1999): Financial liberalization and competition in banking: An empirical investigation, Working Paper, Tel Aviv University

Santos, J. (2000) Bank capital regulation in contemporary banking theory: a review of the literature Working Paper, Bank for International Settlement

Saunders, A./Walter, I. (1994): Universal banking in the United States, Oxford University Press, Oxford/UK.

Schenk, C. (2002): Banding together for SME credit risk analytics, Risk, November 2002, pp. 24-26.

Schmalensee, R. (1989): Inter-industry studies of structure and performance, Handbook of Industrial Organization, ed. b. R.Schmalensee und R. Willig, North Holland, Amsterdam, pp. 951-1001

Schmidt, R.H. (2001): The future of banking in Europe, Financial Markets and Portfolio Management 15, pp. 429-449.

Shaffer, S. (1993): A test of competition in Canadian banking, Journal of Money, Credit, and Banking 25, pp. 49-61.

Shleifer, A./Vishny, R. (1998): The grabbing hand, Harvard University Press, Cambridge Mass. 
Sironi, A. (2000): Testing for market discipline in the European banking industry: Evidence from subordinated debt issues, (forthcoming Journal of Money, Credit, and Banking).

Skelly, J. (2002): Change now or lose business later, European Banker, October 2002, p. 2.

Spiller, P./Favero, E. (1984): The effects of entry regulation on oligopolistic interaction: The Uruguayan banking sector, RAND Journal of Economics 9, pp. 305-327.

Sutton, J. (1991): Sunk cost and market structure, MIT Press, Cambridge Mass.

Stigler, G.J. (1971): The theory of economic regulation, Bell Journal of Economics and Management Science 2, pp. 1-21.

Stiglitz, J.E. (2001): Principles of financial regulation: A dynamic portfolio approach, The World Bank Resreach Observer 16, pp. 1-18.

Theodore, S. (2003): Caution reigns over Germany for 2003, The Banker, March 2003, p. 12.

Vander Vennet, R. (2002): Cost and profit efficiency of financial conglomerates and universal banks in Europe, Journal of Money, Credit, and Banking 34, pp. 254-282.

Vives, X. (1991): Banking competition and European integration, European Financial Integration, hrsg. v. A. Giovannini u. C. Mayer, Cambridge University Press, Cambridge/UK, S. 9-31

Vives, X. (1999): Lessons from European banking liberalization and integration, Working Paper, Institut d'Analisi Economica, Barcelona.

Vives, X. (2000): Central banks and supervision (with an application to financial architecture in EMU), Institut d'Analisi Economica, Barcelona.

Winton, A. (1999): Don't put all eggs in one basket: Diversification and specialization in lending, Working Paper, University of Minnesota.

Zarutskie, R. (2003): Does bank competition affect how much firms can borrow? New evidence from the U.S., Working Paper MIT. 
APPENDIX - Tables and Figures 
Table 1:

\begin{tabular}{|c|c|}
\hline Year & Event \\
\hline 1957 & Bundesbank Act \\
\hline 1958 & Branching restrictions abolished \\
\hline 1961 & German Banking Act \\
\hline 1965 & Interest rate regulation by FBSO replaces cartel agreements among banks \\
\hline 1967 & Interest rate regulation completely abolished \\
\hline 1968 & $\begin{array}{l}\text { German banks and Bundesbank enter into so called "Gentlemen's Agreement" } \\
\text { effectively prohibiting foreign banks from underwriting issues of DM-denominated } \\
\text { bonds by foreign issuers }\end{array}$ \\
\hline 1969 & Introduction of first group specific deposit insurance schemes \\
\hline \multirow[t]{4}{*}{1974} & Default of Bankhaus Herstatt \\
\hline & $\begin{array}{l}\text { Introduction of Principle Ia that limits open positions in forex and commodities to } \\
30 \% \text { of bank capital }\end{array}$ \\
\hline & Establishment of the Liquiditäts-Konsortialbank GmbH \\
\hline & $\begin{array}{l}\text { Expert group on "Grundsatzfragen der Kreditwirtschaft" (fundamental issues of the } \\
\text { banking industry) }\end{array}$ \\
\hline 1976 & $\begin{array}{l}\text { Second Amendment to the German Banking Act } \\
\text { - new rules for large loans to single borrowers } \\
\text { - } \quad \text { new rules on credit files } \\
\text { - } \quad \text { FBSO authorised to audit single institutions without specific reason } \\
\text { - } \quad \text { explicit limits on bank losses that oblige FBSO to close the bank }\end{array}$ \\
\hline 1974-1977 & $\begin{array}{l}\text { Enlargement/adjustment of group-specific deposit insurance schemes for private } \\
\text { banks, public banks, and co-operative banks respectively } \\
\text { - } 1975 \text { Public savings banks } \\
\text { - } 1976 \text { Private banks } \\
\text { - } 1977 \text { Co-operative banks }\end{array}$ \\
\hline 1980 & Expansion of the "Gentlemen's Agreement" \\
\hline 1983 & Near collapse of Bankhaus Schröder, Münchmeyer \& Hengst \\
\hline \multirow[t]{3}{*}{1985} & $\begin{array}{l}\text { Third amendment to the German Banking Act } \\
\text { - Capital requirements to be met on consolidated basis } \\
\text { - New limit for lending to a single borrowing entity }\end{array}$ \\
\hline & Abolition of the "Gentlemen's Agreement" \\
\hline & Permission to issue DM-denominated zerobonds \\
\hline 1986 & Permission to issue DM-denominated Certificates of Deposit \\
\hline 1990 & First Financial Market Promotion Act \\
\hline 1993 & $\begin{array}{l}\text { Fourth amendment to the Banking Act implementing the EU } \\
\text { - Solvency Directive and } \\
\text { - Capital Adequacy Directive } \\
\text { - Threshold for large loans to be reported to the Bundesbank's credit register } \\
\text { raised from } € 500,000 \text { to } € 1,500,000\end{array}$ \\
\hline 1994 & $\begin{array}{l}\text { Second Financial Market Promotion Act } \\
\text { - Introduction of Money Market Mutual Funds (Amendment to the Investment } \\
\text { Company Act) } \\
\text { - Prohibition of insider trading } \\
\text { - Establishment of Federal Supervisory Office for Securities Trading }\end{array}$ \\
\hline 1995 & $\begin{array}{l}\text { Fifth amendment to the Banking Act implementing new rules on consolidation and } \\
\text { large credits }\end{array}$ \\
\hline 1998 & $\begin{array}{l}\text { Sixth amendment to the Banking Act implementing EU's } \\
\text { - Investment Services Directive } \\
\text { - Capital Adequacy Directive and } \\
\text { - } \quad \text { Post-BCCI Directive }\end{array}$ \\
\hline 1999 & FBSO creates division supervising "complex groups" \\
\hline 2002 & $\begin{array}{l}\text { Establishment of an integrated financial services supervisor - the Federal Financial } \\
\text { Supervisory Authority - integrating the formerly separated supervisory offices for } \\
\text { banking, insurance and securities trading }\end{array}$ \\
\hline
\end{tabular}


Table 2: $\quad$ Measures of local banking market concentration - Herfindahl indices based on branching data

\begin{tabular}{|c|c|c|c|c|}
\hline Markets & $\begin{array}{c}\text { No. of } \\
\text { local } \\
\text { markets }\end{array}$ & $\begin{array}{c}\text { Average } \\
\text { Herfindahl } \\
1996 \\
\end{array}$ & $\begin{array}{c}\text { Average } \\
\text { Herfindahl } \\
1998 \\
\end{array}$ & $\begin{array}{c}\text { Average } \\
\text { Herfindahl } \\
2000 \\
\end{array}$ \\
\hline Western Germany & 328 & 0.198 & 0.200 & 0.206 \\
\hline Eastern Germany & 112 & 0.280 & 0.302 & 0.325 \\
\hline $\begin{array}{l}\text { among them: } \\
\text { Cities } \\
\text { (Eastern and Western } \\
\text { Germany) }\end{array}$ & 111 & 0.210 & 0.214 & 0.212 \\
\hline Western Germany & & & & \\
\hline Densely populated areas & 120 & 0.200 & 0.202 & 0.205 \\
\hline Urbanized areas & 140 & 0.196 & 0.197 & 0.205 \\
\hline Rural areas & 68 & 0.199 & 0.202 & 0.211 \\
\hline Eastern Germany & & & & \\
\hline Densely populated areas & 30 & 0.284 & 0.298 & 0.329 \\
\hline Urbanized areas & 47 & 0.296 & 0.321 & 0.338 \\
\hline Rural areas & 35 & 0.255 & 0.280 & 0.306 \\
\hline
\end{tabular}

Source: Fischer (2001) 
Table 3: $\quad$ Bank market structure in largest German cities (\# 83)

\begin{tabular}{lcc} 
& Mean/Median & Minimum/Maximum \\
\hline $\begin{array}{l}\text { \# of banks that operate } \\
\text { branches in a local market }\end{array}$ & $25 / 20$ & $6 / 87$ \\
\hline $\begin{array}{l}\text { \# of savings banks that } \\
\text { operate branches in a local } \\
\text { market }\end{array}$ & $1.3 / 1$ & $1 / 7$ \\
\hline $\begin{array}{l}\text { \# of Landesbanks that operate } \\
\text { branches in a local market }\end{array}$ & $0.6 / 0$ & $0 / 4$ \\
\hline $\begin{array}{l}\text { \# of cooperative banks that } \\
\text { operate branches in a local } \\
\text { market }\end{array}$ & $6 / 5$ & $1 / 19$ \\
\hline $\begin{array}{l}\text { \# of private banks that operate } \\
\text { branches in a local market }\end{array}$ & $17 / 12$ & $4 / 68$ \\
\hline $\begin{array}{l}\text { \# of bank branches } \\
\text { branches per 1,000 capita }\end{array}$ & $112 / 69$ & $26 / 867$ \\
\hline $\begin{array}{l}\text { branches per square kilometer } \\
\text { Herfindahl (based on branch }\end{array}$ & $0.39 / 0.39$ & $0.21 / 0.67$ \\
\hline data)
\end{tabular}

Authors' own calculations based on data from Fischer (2001) 
Table 4: $\quad$ Bank market concentration as a determinant of bank interest margins -

Regression results

\begin{tabular}{|c|c|c|c|}
\hline & $\begin{array}{l}\text { Margin Savings } \\
\text { Deposits }\end{array}$ & $\begin{array}{l}\text { Margin Time } \\
\text { Deposits }\end{array}$ & $\begin{array}{c}\text { Margin } \\
\text { Discount Loans }\end{array}$ \\
\hline 1YEARGRO & 0.08 & -0.09 & $0.53^{\mathrm{a}}$ \\
\hline PCINC & $-0.10^{\mathrm{a}}$ & 0.03 & $-0.36^{\mathrm{a}}$ \\
\hline POPGRO & 0.47 & -0.89 & $6.06^{\mathrm{a}}$ \\
\hline UNEMPLOY & $-0.95^{\mathrm{a}}$ & 0.04 & $-2.21^{\mathrm{a}}$ \\
\hline RURAL & 0.08 & $0.03^{\mathrm{c}}$ & $0.12^{\mathrm{b}}$ \\
\hline HERF & $0.15^{\mathrm{b}}$ & 0.09 & $2.03^{\mathrm{a}}$ \\
\hline \# Obs. $/ \mathrm{R}^{2}$ & $5873 / 0.94$ & $5943 / 0.52$ & $5500 / 0.20$ \\
\hline \multicolumn{4}{|c|}{$\begin{array}{l}\text { Authors' own calculations based on data from Fischer (2001) } \\
\text { a Significantly different from zero at } 1 \% \text { level } \\
\text { bignificantly different from zero at } 5 \% \text { level } \\
\text { ' Significantly different from zero at } 10 \% \text { level } \\
\text { IYEARGRO: Percentage growth in respective product category of all cooperative and } \\
\quad \text { savings banks' headquarters located in the local market. } \\
\text { PCINC: Average annual per capita income in local market. } \\
\text { POPGRO: Annual growth in population in local market. } \\
\text { UNEMPLOY: Average annual rate of unemployment in local market. } \\
\text { RURAL: Dummy variable indicating rural market. } \\
\text { HERF: Herfindahl index of local bank concentration based on branching data. } \\
\text { Pooled-OLS- regressions include a constant, } 15 \text { quarterly dummies, and } 10 \text { dummies for } \\
\text { states (coefficients not reported). }\end{array}$} \\
\hline
\end{tabular}


Table 5: $\quad$ Market structure in German IPO underwriting (1990 - 2000) - Bookrunners

\begin{tabular}{|c|c|c|c|c|c|}
\hline Year & $\begin{array}{l}\text { IPO volume } \\
\text { (Euro mio) } \\
\text { [\# of IPOs] }\end{array}$ & $\begin{array}{l}\text { Herfindahl - } \\
\text { bookrunners }\end{array}$ & $\begin{array}{c}\text { \# of Banks } \\
\text { acting as } \\
\text { lead } \\
\text { underwriter }\end{array}$ & $\begin{array}{c}\text { CR3 -- } \\
\text { Bookrunners }\end{array}$ & $\begin{array}{l}\text { \% Share of } \\
\text { foreign } \\
\text { banks in } \\
\text { total volume }\end{array}$ \\
\hline 1990 & $\begin{array}{c}1,545.13 \\
{[34]}\end{array}$ & 0.32 & 5 & 90.05 & 0 \\
\hline 1991 & $\begin{array}{c}1,494.84 \\
{[19]} \\
\end{array}$ & 0.30 & 7 & 84.81 & 0 \\
\hline 1992 & $\begin{array}{c}373.98 \\
{[9]}\end{array}$ & 0.34 & 4 & 89.34 & 0 \\
\hline 1993 & $\begin{array}{c}475.78 \\
{[11]}\end{array}$ & 0,37 & 4 & 94.41 & 0 \\
\hline 1994 & $\begin{array}{c}596.73 \\
{[15]} \\
\end{array}$ & 0.28 & 7 & 77.44 & 1.01 \\
\hline 1995 & $\begin{array}{c}3,583.03 \\
{[20]}\end{array}$ & 0.29 & 10 & 89.12 & 35.64 \\
\hline 1996 & $\begin{array}{c}9,054.48 \\
{[14]} \\
\end{array}$ & 0.32 & 9 & 98.65 & 33.24 \\
\hline 1997 & $\begin{array}{c}2,529.75 \\
{[36]}\end{array}$ & 0.13 & 16 & 47.07 & 26.42 \\
\hline 1998 & $\begin{array}{c}4,098.87 \\
{[79]} \\
\end{array}$ & 0.08 & 29 & 38.52 & 27.09 \\
\hline 1999 & $\begin{array}{c}12,731.013 \\
{[175]}\end{array}$ & 0.11 & 46 & 47.47 & 50.12 \\
\hline 2000 & $\begin{array}{c}25,556.29 \\
{[153]}\end{array}$ & 0.17 & 43 & 65.12 & 44.03 \\
\hline
\end{tabular}

Authors' own calculations based on data kindly provided by Stefanie Franzke,(Center for Financial Studies). In measuring market shares, whenever two or more banks act as bookrunner for one single issue, we double counted the volume of that issue. 
Table 6: $\quad$ Market structure of Euro-denominated bond underwriting (2001) Bookrunners

\begin{tabular}{|c|c|c|c|c|}
\hline $\begin{array}{c}\text { Positio } \\
\text { n }\end{array}$ & Bank & $\begin{array}{c}\text { Volume } \\
\text { in EURO } \\
\text { mio }\end{array}$ & $\begin{array}{l}\text { \# of } \\
\text { issues }\end{array}$ & $\begin{array}{l}\text { \% Share in } \\
\text { volume }\end{array}$ \\
\hline 1 & Dresdner Kleinwort Wasserstein & 26.552 & 168 & 10.45 \\
\hline 2 & Deutsche Bank & 24.209 & 113 & 9.53 \\
\hline 3 & JP Morgan & 21.617 & 40 & 8.51 \\
\hline 4 & Merrill Lynch \& Co. & 21.446 & 68 & 8.44 \\
\hline 5 & Salomon Smith Barney Int. & 16.113 & 59 & 6.34 \\
\hline 6 & Morgan Stanley Dean Witter & 16.047 & 68 & 6.32 \\
\hline 7 & Goldman Sachs \& Co. & 13.660 & 53 & 5.38 \\
\hline 8 & Commerzbank Sec. & 10.180 & 92 & 4.01 \\
\hline 9 & Barclays Capital & 9.866 & 74 & 3.88 \\
\hline 10 & UBS Warburg & 8.077 & 27 & 3.18 \\
\hline
\end{tabular}

Source: Börsenzeitung based on Capital Data. Calculations of market share excluding own issues and based on total volume of top 30 bookrunners 
Table 7: $\quad$ Capital market reactions to introduction of Money Market Mutual Funds in Germany - Market value of banks

\begin{tabular}{cccc}
\hline Portfolio & $\begin{array}{c}\text { Equally weighted } \\
\text { bank portfolio }\end{array}$ & $\begin{array}{c}\text { Portfolio of small } \\
\text { banks }\end{array}$ & $\begin{array}{c}\text { Portfolio of large } \\
\text { banks }\end{array}$ \\
\hline $\begin{array}{l}\text { CAR }\left[\text { day }_{0}, \mathrm{day}_{+2}\right]^{1)} \text { in } \\
\%\end{array}$ & $-2.4^{\mathrm{a}}$ & $-1.2^{\mathrm{a}}$ & $-3.6^{\mathrm{a}}$ \\
\hline
\end{tabular}

${ }^{a}$ Significantly different from zero at $1 \%$ level.

1) Based on authors' own analysis; cumulative abnormal return for the three-day period $[0,+2]$ upon announcement that the Bundesbank puts aside its reservations against allowing money market funds in Germany in April 1994. The estimated market model includes the daily return on an equally weighted market index (DAFOX), the daily change in the long-term government bond yield and the daily change in the three-month money market rate as explanatory variables; stock price data from Deutsche Kapitalmarktdatenbank, Karlsruhe; data on interest rates from Deutsche Bundesbank 
Table 8: $\quad$ Regulatory capital positions of German banks -results for different banking groups

\begin{tabular}{|c|c|c|c|c|c|}
\hline \multirow[t]{2}{*}{ Bank group } & \multicolumn{2}{|c|}{$\begin{array}{c}\text { Regulatory } \\
\text { capital ratio }\end{array}$} & \multirow{2}{*}{$\begin{array}{c}\text { \%rate of growth } \\
\text { Total assets }\end{array}$} & \multirow{2}{*}{$\begin{array}{l}\text { \%rate of growth } \\
\text { Loans to non- } \\
\text { banks }\end{array}$} & \multirow{2}{*}{$\begin{array}{c}\text { \%rate of growth } \\
\text { Book equity }\end{array}$} \\
\hline & 1993 & 2001 & & & \\
\hline Large private banks & 10.2 & 13.9 & \multirow{2}{*}{\}$\quad 2.78$} & \multirow{2}{*}{ \} 7.49} & \multirow{2}{*}{\} 9.86} \\
\hline Other private banks & 10.3 & 12.9 & & & \\
\hline $\begin{array}{l}\text { Savings banks } \\
\text { (public) }\end{array}$ & 8.9 & 10.8 & 4.62 & 5.18 & 6.76 \\
\hline Co-operative banks & 8.9 & 11.1 & 4.33 & 4.28 & 6.84 \\
\hline Landesbanks (public) & 9.7 & 11.3 & 10.1 & 7.55 & 14.31 \\
\hline $\begin{array}{l}\text { Co-operative central } \\
\text { banks }\end{array}$ & 10.4 & 14.5 & 7.84 & 6.78 & 9.98 \\
\hline
\end{tabular}

Source: Deutsche Bundesbank; \%rate of growth is the nominal average annual growth rate over the 1993 to 2001 period.

1) According to the FBSO's Principle I. The definition of "liable capita"l and a bank's risk assets is largely in line with the first Basle Accord of 1988 and the respective European Directive 
Table 9: $\quad$ SME financing and banking market concentration

\begin{tabular}{|c|c|c|c|}
\hline $\begin{array}{l}\text { Western German sub- } \\
\text { sample }\end{array}$ & $\begin{array}{c}\text { Firms in local markets } \\
\text { with low } \\
\text { concentration of } \\
\text { banks }\end{array}$ & $\begin{array}{c}\text { Firms in local markets } \\
\text { with high } \\
\text { concentration of } \\
\text { banks }\end{array}$ & $\begin{array}{l}\text { t-statistic } \\
\text { (p-value) }\end{array}$ \\
\hline
\end{tabular}

Ratio of bank loans to

total assets

0.17

0.22

3.17

(\# of observations)

(776)

(776)

$(0.00)$

Share of firms with

bank loans in capital

structure

0.55

0.59

1.49

(\# of observations)

(776)

(776)

(0.14)

\begin{tabular}{|c|c|c|c|}
\hline $\begin{array}{l}\text { Eastern German } \\
\text { subsample }\end{array}$ & $\begin{array}{c}\text { Firms in local markets } \\
\text { with low } \\
\text { concentration of } \\
\text { banks }\end{array}$ & $\begin{array}{c}\text { Firms in local markets } \\
\text { with high } \\
\text { concentration of } \\
\text { banks }\end{array}$ & $\begin{array}{l}\text { t-statistic } \\
\text { (p-value) }\end{array}$ \\
\hline $\begin{array}{c}\text { Ratio of bank loans to } \\
\text { total assets } \\
\text { (\# of observations) }\end{array}$ & $\begin{array}{c}0.21 \\
(626)\end{array}$ & $\begin{array}{c}0.28 \\
(626)\end{array}$ & $\begin{array}{c}4.70 \\
(0.00)\end{array}$ \\
\hline $\begin{array}{c}\text { Share of firms with } \\
\text { bank loans in capital } \\
\text { structure } \\
\text { (\# of observations) }\end{array}$ & $\begin{array}{c}0.70 \\
(626)\end{array}$ & $\begin{array}{c}0.78 \\
(626)\end{array}$ & $\begin{array}{c}3.40 \\
(0.00)\end{array}$ \\
\hline
\end{tabular}


Table 10: $\quad$ SME financing and banking market concentration - firms from construction sector

\begin{tabular}{cccc}
\hline \hline $\begin{array}{c}\text { Western German sub- } \\
\text { sample }\end{array}$ & $\begin{array}{c}\text { Group of firms } \\
\text { according to } \\
\text { total assets }\end{array}$ & $\begin{array}{c}\text { Firms in local markets } \\
\text { with low concentration } \\
\text { of banks }\end{array}$ & $\begin{array}{c}\text { Firms in local } \\
\text { markets with high } \\
\text { concentration of } \\
\text { banks }\end{array}$ \\
\hline $\begin{array}{c}\text { Ratio of bank loans to } \\
\text { total assets } \\
\text { (\# of observations) }\end{array}$ & Largest firms & 0.20 & 0.25 \\
\hline $\begin{array}{c}\text { Ratio of bank loans to } \\
\text { total assets } \\
\text { (\# of observations) }\end{array}$ & Firms of & $(64)$ & $(62)$ \\
\hline $\begin{array}{c}\text { Ratio of bank loans to } \\
\text { total assets }\end{array}$ & Smallest firms & 0.19 & 0.21 \\
(\# of observations) & & $(70)$ & $(77)$ \\
\hline
\end{tabular}

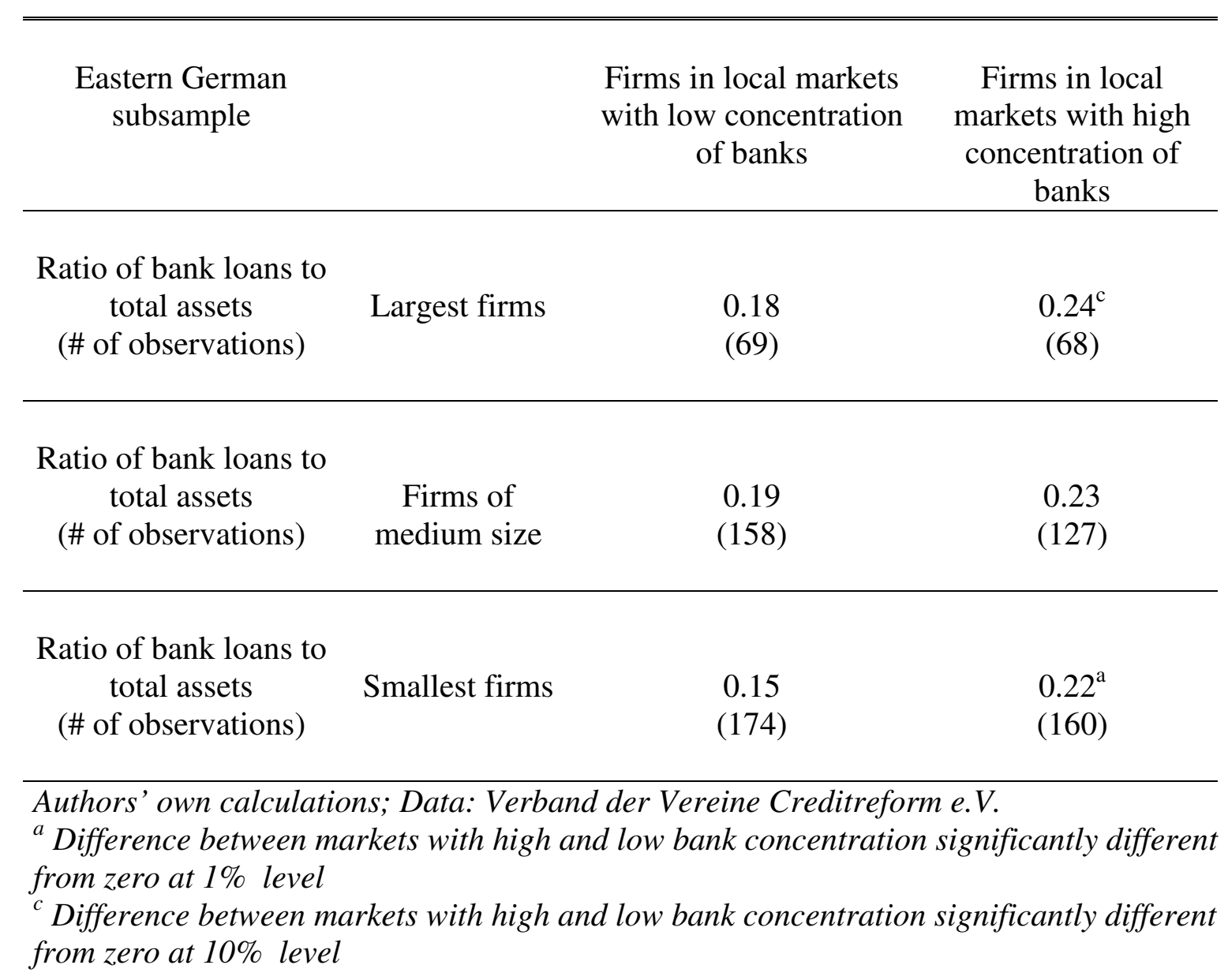


Figure 1: $\quad$ Concentration ratios in large Germen cities (\# 83)

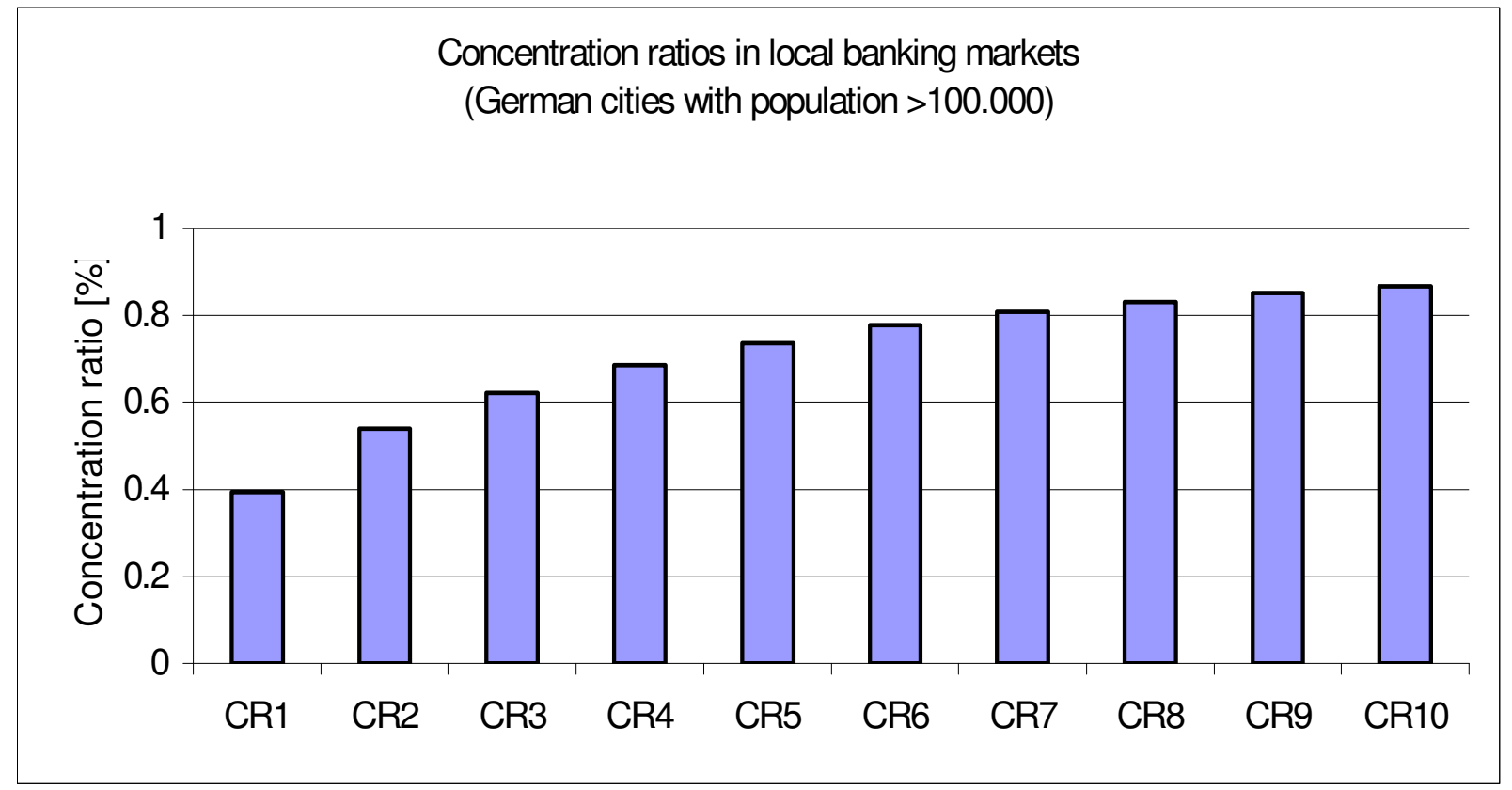

Source: Fischer (2001) 
Figure 2: $\quad$ Market power in German banking - Lerner indices

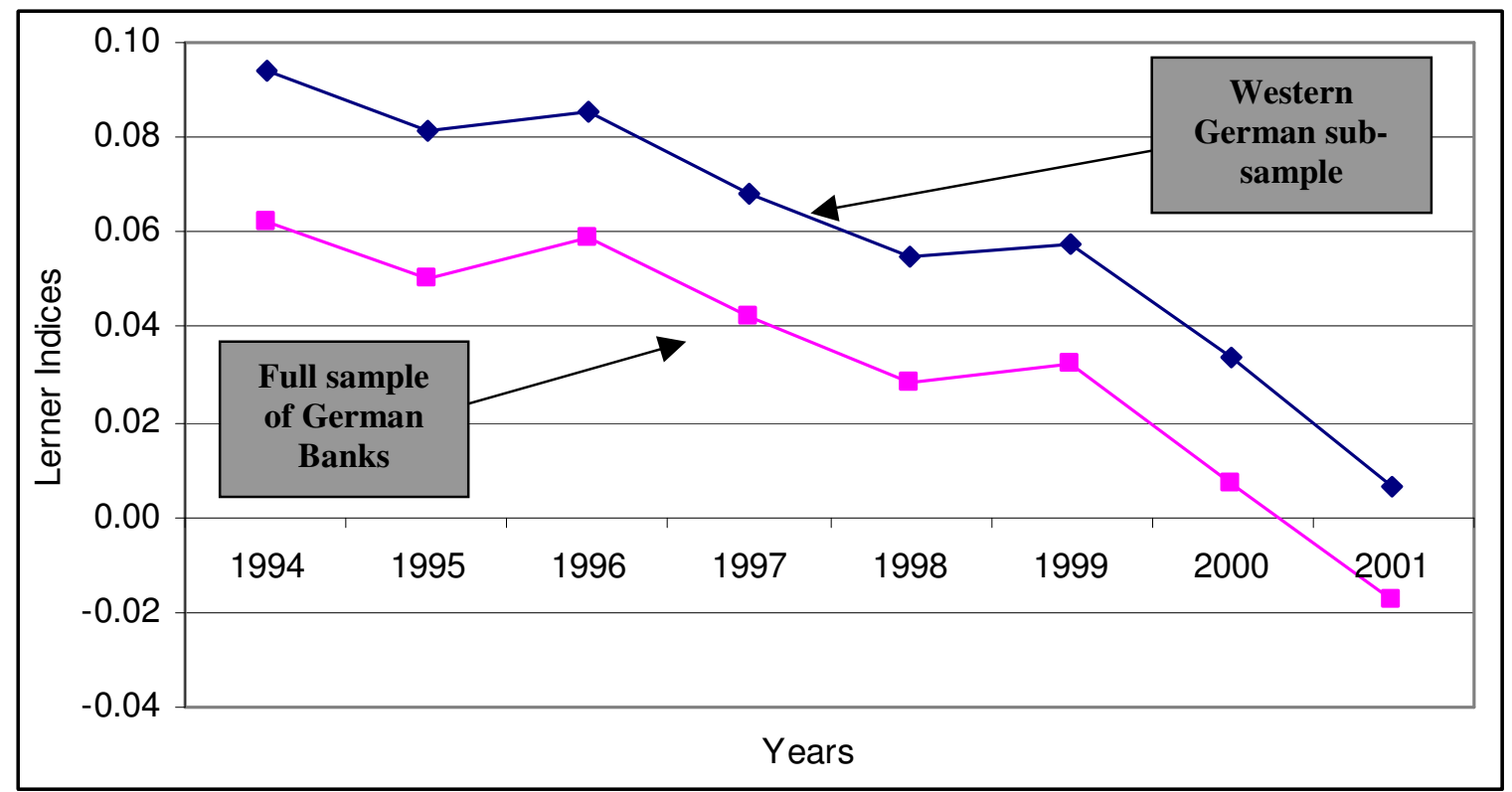

Source: Fischer/Hempell (2003). 
Figure 3: $\quad$ Bank deposit margins and Money Market Mutual Funds

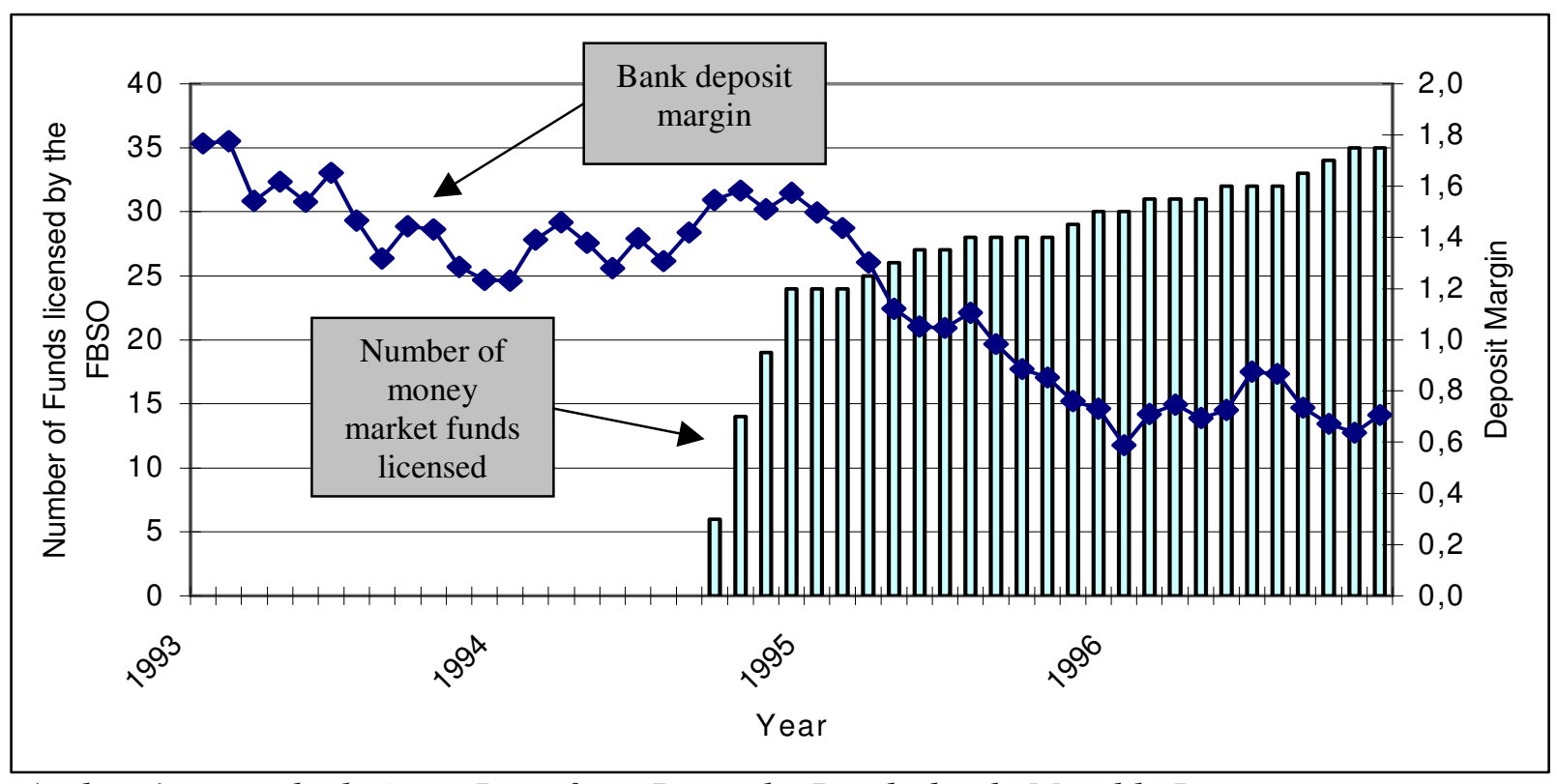

Authors' own calculations; Data from Deutsche Bundesbank, Monthly Reports 
Figure 4 : $\quad$ Regulatory capital positions of German banks (1977-2001)

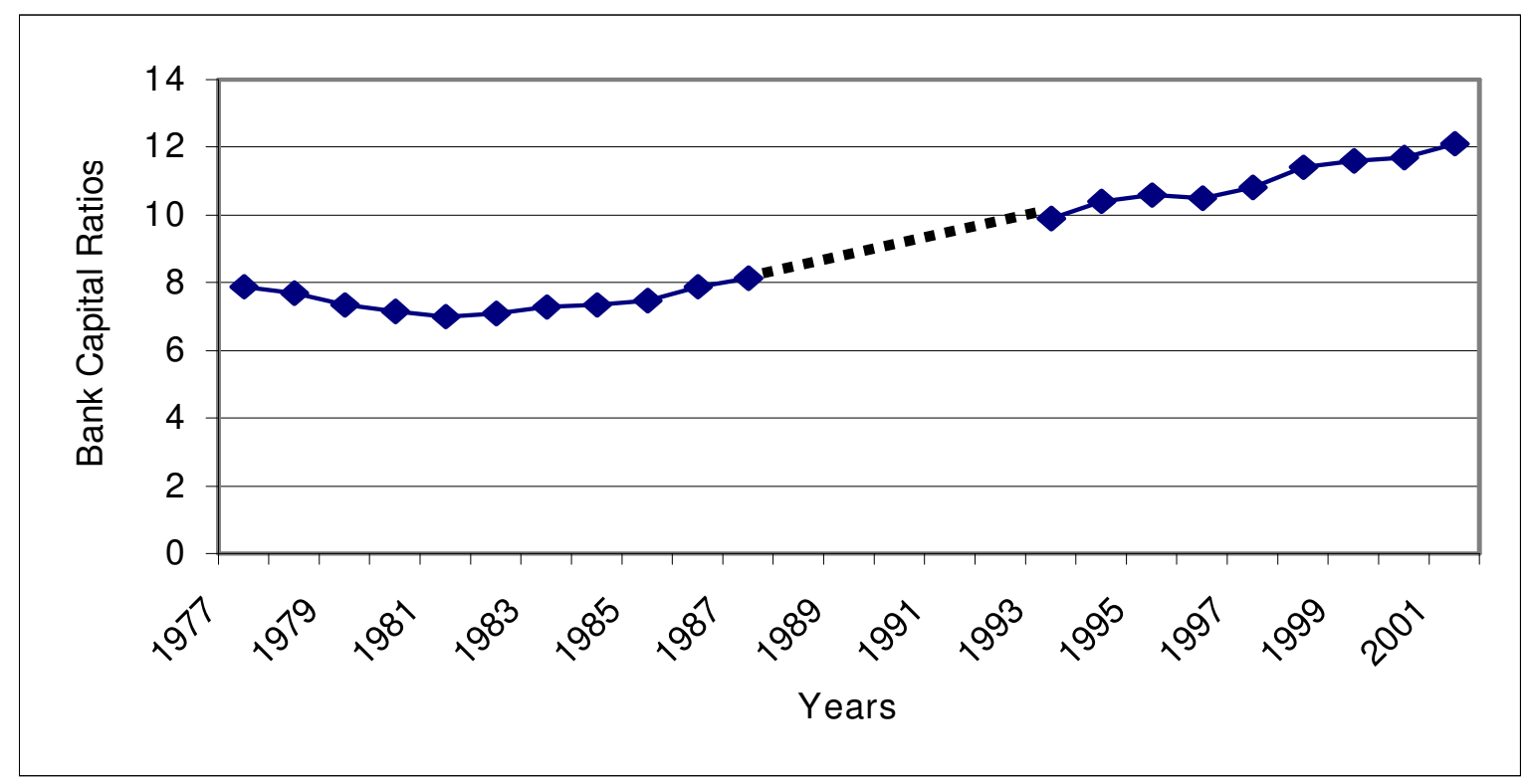

Regulatory bank capital ratio of all German banks. Figures for 1977 to 1988 adapted from Rudolph (1992); figures for 1989 to 1992 not available. Figures for 1993 to 2001 period kindly provided by Deutsche Bundesbank 
Figure 5: $\quad$ Entry and exit in German banking - licensing by the FBSO

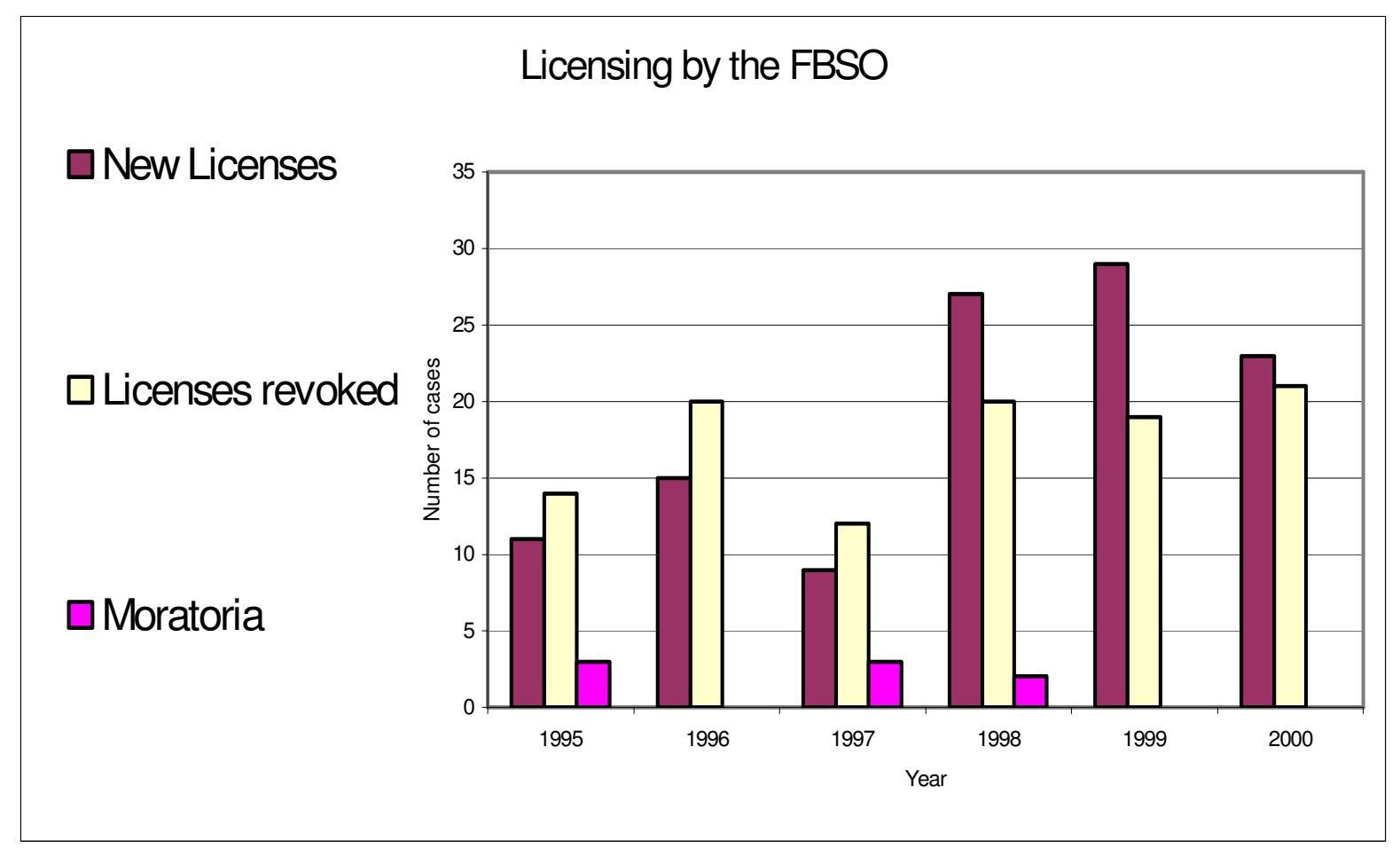

Source: Federal Banking Supervisory Office - Annual Reports 
Figure 6: $\quad$ Frequency of special audits by the FBSO (1992-2000)

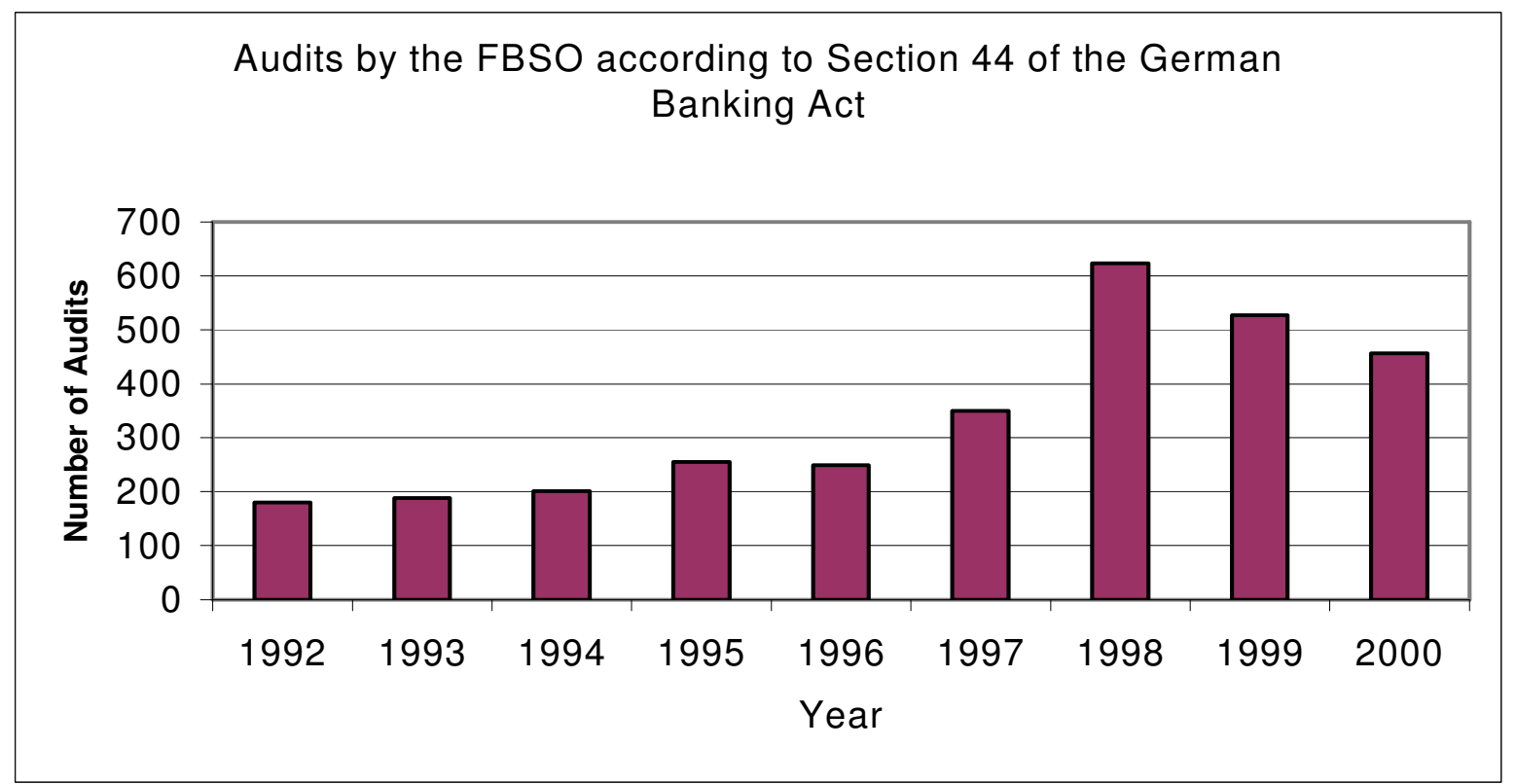

Source: Federal Banking Supervisory Office - Annual Reports 


\section{CFS Working Paper Series:}

\begin{tabular}{lll} 
No. & Author(s) & Title \\
\hline $2003 / 09$ & $\begin{array}{l}\text { Günter Coenen } \\
\text { Volker Wieland }\end{array}$ & $\begin{array}{l}\text { The Zero-Interest-Rate and the Role of the } \\
\text { Exchange Rate for Monetary Policy in Japan }\end{array}$ \\
$2003 / 10$ & $\begin{array}{l}\text { Stefan Reitz } \\
\text { Frank Westerhoff }\end{array}$ & $\begin{array}{l}\text { Nonlinearities and Cyclical Behavior: } \\
\text { The Role of Chartists and Fundamentalists }\end{array}$ \\
& $\begin{array}{l}\text { Stefan Reitz } \\
\text { Ralf Ahrens }\end{array}$ & $\begin{array}{l}\text { Heterogeneous Expectations in the Foreign } \\
\text { Exchange Market Evidence from the Daily } \\
\text { Dollar/DM Exchange Rate }\end{array}$ \\
& $\begin{array}{l}\text { Klaus Adam } \\
\text { Optimal Monetary Policy with }\end{array}$ \\
& & Imperfect Common Knowledge
\end{tabular}

2003/13 Günter Coenen Athanasios Orphanides when Nominal Interest Rates are Bounded at Zero Volker Wieland

2003/14 Raimond Maurer

Institutional Investors in Germany: Insurance Companies and Investment Funds

$\begin{array}{ll}\text { 2003/15 } & \begin{array}{l}\text { Daniel Schmidt } \\ \text { Mark Wahrenburg }\end{array}\end{array}$

2003/16 Christian Leuz Jens Wüstemann

2003/17 Erik Theissen

2003/18 Roman Kräussl

2003/19 Karl-Hermann Fischer Christian Pfeil
Contractual Relations between European VCFunds and Investors: The Impact of Reputation and Bargaining Power on Contractual Design

The Role of Accounting in the German Financial System

Organized Equity Markets in Germany

Do Credit Rating Agencies Add to the Dynamics of Emerging Market Crises?

Regulation and Competition in German Banking: An Assessment

Copies of working papers are available at the Center for Financial Studies or can be downloaded (http://www.ifk-cfs.de). 